\title{
New or poorly known Epermeniidae of the Afrotropis (Lepidoptera, Epermenioidea)
}

\author{
With 105 figures \\ REINHARD GAEDIKE ${ }^{1}$ \\ ${ }^{1}$ Florusstraße 5, 53225 Bonn; email:tinagma@msn.com \\ Published on 2013-06-14
}

\section{Summary}

One new genus (Inuncus) and nineteen new species are described: Phaulernis montuosa, P. africana, Inuncus juratae, Epermenia (Calotripis) paramalawica, E. (C.) karurucola, E. (C.) formosa, E. (C.) dallastai, E. (C.) costomaculata, E. (C.) turicola, E. (C.) hamata, E. (C.) aarviki, E. (C.) ruwenzorica, E. (C.) tenuipennella, E. (Epermenia s. str.) agassizi, E. (Cataplectica) kenyacola, E. (C.) triacuta, Gnathifera punctata, Ochromolopis sagittella, O. cana. Females were described for the first time from Epermenia (Calotripis) malawica Gaedike, 2004, and E. (C.) bulbosa GAEDIKE, 2004. There are established new country records for seven species (Africepermenia tanzanica GAEDIKE, 2004, Epermenia (Calotripis) criticodes Meyrick, 1913, E. (C.) conioptila Meyrick, 1921, E. (C.) meyi Gaedike, 2004, E. (C.) malawica Gaedike, 2004, E. (C.) bulbosa Gaedike, 2004, E. (C.) iniquella (Wocke, 1867) [=ochrodesma Meyrick, 1913]).

Recenty are known 41 species from the Afrotropical Region.

\section{Zusammenfassung}

Es werden eine neue Gattung (Inuncus) und neunzehn neue Arten beschrieben: Phaulernis montuosa, P. africana, Inuncus juratae, Epermenia (Calotripis) paramalawica, E. (C.) karurucola, E. (C.) formosa, E. (C.) dallastai, E. (C.) costomaculata, E. (C.) turicola, E. (C.) hamata, E. (C.) aarviki, E. (C.) ruwenzorica, E. (C.) tenuipennella, E. (Epermenia s. str.) agassizi, E. (Cataplectica) kenyacola, E. (C.) triacuta, Gnathifera punctata, Ochromolopis sagittella, O. cana. Erstmals werden die Weibchen von Epermenia (Calotripis) malawica Gaedike, 2004 und E. (C.) bulbosa Gaedike, 2004 beschrieben. Für sieben Arten (Africepermenia tanzanica Gaedike, 2004, Epermenia (Calotripis) criticodes Meyrick, 1913, E. (C.) conioptila Meyrick, 1921, E. (C.) meyi Gaedike, 2004, E. (C.) malawica Gaedike, 2004, E. (C.) bulbosa Gaedike, 2004, E. (C.) iniquella (Wocke, 1867)[= ochrodesma Meyrick, 1913]) erfolgen Erstnachweise für einzelne Länder.

Gegenwärtig sind 41 Arten aus der afrotropischen Region bekannt. 


\section{Introduction}

Only some years after publication of two papers about the Afrotropical Epermeniidae (GAEDIKe, 2004; 2004a) I have had the opportunity to study a rich material of this family, which was recently collected in several parts of the region. The main part of the studied 109 specimens was collected by members of the staff (JURATE De Prins, UGo DALL'Asta) of the Royal Museum for Central Africa, Tervuren Belgium, the other specimens were collected by LeIf Aarvik, Natural History Museum, University Oslo, Norway, David J. L. Agassiz/North Somerset, Great Britain, and Wolfram Mey, Museum für Naturkunde der Humboldt-Universität, Berlin, Germany. Additionally were studied some specimens from the collections of Muséum d'Histoire Naturelle, Genève, Switzerland and of the Zoologische Staatssammlung, Munich, Germany.

The result from examination of the specimens was the discovery of nineteen new species and one new genus. For two species were discovered females for the first time, and for seven species were determined new country records.

For the possibility to study this interesting material I thank L. Aarvik (NHMO, Oslo), D. J. L. Agassiz (North Somerset), B. Landry (MHNG, Genève), W. Mey (ZMHB, Berlin), J. De Prins (RMCA, Tervuren), A. Segerer (ZSM, Munich).

I thank A. D. Liston (Müncheberg) for linguistic corrections and $\mathrm{CH}$. Kutzscher (Müncheberg) for preparing the colour photographs.

\section{Abbreviations}

coll. Agassiz $\quad$ D. J. L. Agassiz/North Somerset, Great Britain

BMNH British Museum of Natural History, London, Great Britain

MHNG Muséum d'Histoire Naturelle (B. Landry), Genève, Switzerland

NHMO Natural History Museum (L. Aarvik), University Oslo, Norway

NMK National Museum of Kenya, Nairobi, Kenya

SDEI Senckenberg Deutsches Entomologisches Institut, Müncheberg, Germany

RMCA Royal Museum for Central Africa (J. De Prins), Tervuren Belgium

ZMHB Museum für Naturkunde der HumboldtUniversität (W. Mey), Berlin, Germany

ZSM Zoologische Staatssammlung (A. Segerer), Munich, Germany

\section{Systematics}

\section{Africepermenia tanzanica GAEDIKE, 2004}

Kenya: $10^{\star}$, Kakamega Forest, $1645 \mathrm{~m}, 00^{\circ} 20^{\prime} \mathrm{N}, 34^{\circ} 51^{\prime} \mathrm{E}$, 14.x.2001, leg. J. De Prins; RMCA ENT 000003201; RMCA.

New country record, previously known only from location of the type series (Tanzania).

\section{Phaulernis montuosa sp. $\mathrm{n}$.}

Holotype ơ, "Coll. Museum Tervuren, Kenya: Taita Hills 05/07/1998 (N3), Ngangao Forest, [leg.] U. Dall'Asta;" "RMCA ENT 000003247;" "Gen.präp. [genitalia slide] Gaedike Nr. 7051;" "Holotypus o Phaulernis montuosa sp. n. det. R. Gaedike 2011;” RMCA.

Paratypes: $10^{\star}$, "Coll. Museum Tervuren, Kenya: Taita Hills 25/06/1998 (E3), Mbololo Forest, [leg.] U. Dall'Asta;" "RMCA ENT 000003246;" SDEI; 1 + "Coll. Museum Tervuren, Kenya: Taita Hills 26/06/1998 (F3), Mbololo Forest Edge, [leg.] U. Dall'Asta;" "RMCA ENT 000003248;" RMCA; 1 specimen without abdomen, "Coll. Museum Tervuren, Kenya: Taita Hills 10/08/1999 (G5), Mbololo plantation, [leg.] U. Dall'Asta Hg. + Hal.;” "RMCA ENT 000003249;" RMCA; 1 specimen without abdomen, "Staatss.[ammlung] München, Tanganyika sept. Mt. Meru Momella, 1600-1800 m, 26.i.1964, leg. [W.] Forster;" ZSM; $10^{\star}$, "Malawi, Mt. Mulanje 1000 m, $15^{\circ} 58^{\prime}$ S, 3539'E, [leg.] D. J. L. Agassiz;” coll. Agassiz.

Derivatio nominis: The name refers to the montane locations of the type series.

Diagnosis (Fig. 1): Wingspan 15 - 17 mm; head light yellow, laterally, around eyes dark brown; labial palpi long, curved, outside yellowish-brown, inside lighter; scape of antenna yellowish-brown, basally with pecten of some scales, flagellum darker brown; thorax and tegulae dark brown; forewing on dorsum with three black tufts of raised scales at $1 / 3,1 / 2$ and $2 / 3$; ground colour of wing dark brown, the basal third somewhat darker than the other part; on costa, opposite the first tuft, a white stripe, reaching the cell, in middle of wing, after $1 / 2$, above third tuft and on apex each a minute white dot, fringe with two sickle-shaped dark brown scale lines; hindwing shining grey.

Male genitalia (Fig. 22-24): Uncus slender, slightly curved, with pointed tip; tegumen mid-dorsally and along margin stronger sclerotised; valva as long as uncustegumen, stout, ampulla with strong sclerotised border to valva, narrower to pointed tip, cucullus with rounded tip, protruding ampulla, sacculus ends into a narrow pointed tip below border of ampulla; phallus shorter than valva, parallelsided, without cornutus. 
Female genitalia (Figs 25-26): Proximal edge of segment VIII slightly immersed in the middle, ostium somewhat broader than ductus bursae, nearly the whole ductus and the beginning of corpus bursae with numerous minute sclerotisations, signum exists as some rows of strong sclerotised various-sized thorns.

Phaulernis africana sp. n.

Holotype ơ, "Kenya, Kakamega Forest 1575 m, 00²0'N, 034 52'E. 01.iv.2003, leg. J. \& W. De Prins;" "RMCA ENT 000003205;" "Gen.präp. [genitalia slide] Gaedike Nr. 7046;" "Holotypus o Phaulernis africana sp. n. det. R. Gaedike 2011;” RMCA.

Paratype: 1 ㅇ " “Tanzania, Iringa Udzungwa Mts $1200 \mathrm{ft}$, 750'45"S, 3653'E, 12.v.2001, [leg.] D. J. L. Agassiz;” coll. Agassiz.

Derivatio nominis: The name refers to the continent of the type location.

Diagnosis (Fig. 2): Wingspan $11 \mathrm{~mm}$; head pale yellowish, tips of scales dark grey; labial palpi short, curved, inside pale yellowish too, outside overlaid with numerous dark grey scales; scape of antenna with same colouration, pecten basally pale, apically dark grey, flagellum ringed; thorax and tegulae light clay-coloured, tegulae basally overlaid with dark grey scales; forewing on dorsum with three tufts of raised scales at $1 / 3,1 / 2$ and $2 / 3$, the first two tufts large, connected, the third clear smaller; ground colour of wing clay-coloured, pale yellow are an area at base above dorsum, a large patch from costa to cell, opposite the first tuft, and a smaller patch on costa opposite the third tuft; between this patch and the tuft a small dark grey patch, apex pale yellow, fringe with dark scales; hindwing grey.

Male genitalia (Figs 27-29): Uncus slender, laterally in the basal half with stronger sclerotised edges; tegumen middorsally and at basal margin stronger sclerotised; valva as long as uncus-tegumen, ampulla curved, border to valva strong sclerotised, cucullus protruding ampulla, sacculus ends in a thin pionted tip below border of ampulla; phallus appr. 2/3 of the lenght of valva, straight, without cornutus.

Female genitalia (Figs 30-31): Proximal edge of segment VIII immersed in the middle, ostium and the first part of ductus bursae with numerous minute sclerotisations, ductus below ostium with one torsion; corpus bursae partly covered with minute sclerotisations, signum small, elongate-oval, with strong sclerotised keel.

The external characteristics and the main structures of the genitalia shows, that the described below species belongs to the family Epermeniidae but, the absence of uncus in male genitalia separates this taxon from all other known members of this family. This is why the new species will described as representant of a new genus.

\section{Inuncus gen. $\mathrm{n}$.}

Type species: Inuncus juratae sp. n. by present designation.

Derivatio nominis: The name refers to the lack of uncus [latin "in-" = without]

Diagnosis (Fig. 3): Wingspan 8 - $10 \mathrm{~mm}$; head, labial palpi, thorax and tegulae pale yellowish to light brown, scales with grey tip, antenna dark grey, scape with pecten; abdomen without abdominal pockets; forewing on dorsum with tufts of raised scales at before and behind $1 / 2$, both tufts large, at 3/4 a small tuft and an indication of a forth one; ground colour of wing brown, with a pattern of lighter and dark scales: dark, nearly black, are in the middle one minute dot above first tuft on the end of a whitish area from costa, overlaid with grey scales, a larger dot above third tuft, above surrounded by thin white line, and the area around apex, the dark scales on fringe forming two sickle-shaped lines; the dark area above apex connected by narrow dark stripe with the larger dot, hindwing gey-brown.

Male genitalia (Figs 32-34): Tegumen triangular, lateral margin bristled; valva nearly two times longer than tegumen, narrow, ampulla hook-shaped, tip various-shaped (see fig. 33), border to valva without stronger sclerotisation, cucullus much longer than ampulla, parallelsided, with rounded tip, cucullus without any sclerotised tip, apical margin bristled; phallus as long as valva, one side strong sclerotised, cornutus small, elongate-oval.

Female genitalia (Figs 35-36): Proximal edge of segment VIII truncated, ductus bursae in the first half with a strong sclerotised broad band, corpus bursae covered by minute strong sclerotised blunt thorns, without signum.

Inuncus juratae sp. n.

Holotype $0^{*}$, "Kenya $18 \mathrm{~km}$ SW Malindi Watamu, $35 \mathrm{~m}$, 0322'S 03959'E, 15.iii.2004, leg. J. \& W. De Prins;" "RMCA ENT 000003199;" "Gen.präp. [genitalia slide] Gaedike Nr. 7047;" "Holotypus or Inuncus juratae sp. n. det. R. Gaedike 2011;” RMCA.

Paratypes: 1 ㅇ with same data as holotype; "RMCA ENT 000003197;" RMCA; 1 क , "Kenya Arabuko Sokoke Forest, $5 \mathrm{~km}$ W Gede, $03^{\circ} 18^{\prime} \mathrm{S}$ 039 $59^{\circ} \mathrm{E}$, 15.iii.2004, leg. J. \& W. De Prins;" "RMCA ENT 000003198;" SDEI; 1 specimen, genitalia lost, "Coll. Museum Tervuren Kenya: Arabuko Sokoke Brachystegia, 2/12/2000 alt. 243 m, 
0319'S 3956'E (K7), [leg.] Ugo Dall'Asta;" "RMCA ENT 000003215;" RMCA; 1 \%, “Tanzania, Morogoro Distr. \& Twon, Kigurunyembe 700-900 m, 27.ii.1992, leg. L. Aarvik;" NHMO.

Derivatio nominis: Named after my colleague, the curator in the Tervuren Museum, Jurate De Prins, she make it possible for me to study the newly collected material from this museum.

Diagnosis, male and female genitalia: See description of the genus.

\section{Epermenia (Calotripis) criticodes MeYRICK, 1913}

Kenya: $1 \sigma^{\star}$, Taita Hills, 1600 m, Ngangao, Ocinium suave, $03^{\circ} 22^{\prime} S$, 38 21'E, 9.iv.2001, leg. J. \& W. De Prins; RMCA ENT 000003195; RMCA; RSA: $1 \sigma^{*}$, Cape Town, Constantia Vista, 17.x.2009, leg. W. Mey; ZMHB; 2 ㅇ, RSA, Stellenbosch, Jonkershoek, $185 \mathrm{~m}$, Glenconner Cott., 28.ix.-3.x.2008, leg. W. Mey; ZMHB; SDEI.

New country record, previously known only from type location (RSA).

\section{Epermenia (Calotripis) conioptila MeYRICK, 1921}

Kenya: 1 , Rift Valley province: Gilgil 2110 m, 37MBV 0668 4636, 22.-24.xi.2008, leg. L. Aarvik, D. Agassiz, A. Kingston; coll. Agassiz.

New country record, previously known only from type location (Simbabwe).

\section{Epermenia (Calotripis) meyi GAEDIKE, 2004}

Kenya: $2 \sigma^{\star}$, Rift Valley, Turi, 8000 ft, 3., 8.iii.2000, [leg.] D. J. L. Agassiz; coll. Agassiz; SDEI; 1 specimen without abdomen, Rift Valley, L. Baringo, $3000 \mathrm{ft}, 24 .-25$. viii.1999, leg. et coll. D. J. L. Agassiz; Ethiopia: $1 \sigma^{*}$, Addis Abeba, 17.iv.1980, leg. Angenstein; ZMHB.

New country records, previously known only from type location (Malawi).

\section{Epermenia (Calotripis) malawica GAEDIKE, 2004}

Kenya: 1 ㅇ, Gatamayo Forest, $00^{\circ} 58^{\prime} \mathrm{S}, 036^{\circ} 41^{\prime} \mathrm{E}$, 4.iv.2003, leg. J. \& W. De Prins; RMCA ENT 000003194; RMCA.

New country record, previously known only from type location (Malawi), and for the first time a female specimen, which is described below (Figs 37-38):
Proximal edge of segment VIII truncated, laterally rounded; laterally each a oval stronger sclerotisation; ostium somewhat funnel-shaped, stronger sclerotised than ductus bursae, corpus bursae partly covered with numerous minute sclerotisations, signum hook-shaped, with larger rounded basal part.

\section{Epermenia (Calotripis) paramalawica sp. n.}

Holotype $\sigma^{*}$, "Kenya, Central, Gatamayo Forest, 0058'00"S, 3641'37"E, 2120 m, MV Light, 17-viii.1999, [leg.] D. J. L. Agassiz;” “Gen.präp. [genitalia slide] Gaedike Nr. 7020;" "Holotypus ơ Epermenia paramalawica sp. n. det. R. Gaedike 2011;” NMK.

Paratypes: 1 ㅇ, same data as holotype; SDEI; 1 ㅇ, "Kenya Rift valley, Molo, 8600 ft, 27.iii.1999, [leg.] D. J. L. Agassiz;" coll. Agassiz; 1 \% , "Coll. Museum Tervuren, Kenya: Taita Hills, 05/03/1999 (C4), Ngangao mixed forest, [leg.] U. Dall'Asta Hg+Hal.;" "RMCA ENT 000003212;"RMCA; 1 우 , "Coll. Museum Tervuren, Kenya: Aberdares Nat. Park 24/11/2000, Karuru Falls, alt. 2980 m, 00²2'S, 36 $54^{\circ} \mathrm{E}$ (D7), [leg.] Ugo Dall'Asta;" "RMCA ENT 000003211;" RMCA.

Derivatio nominis: Named after the similarity to E. malawica in the shape of the male genitalia.

Diagnosis (Fig. 4): Wingspan 13 - $15 \mathrm{~mm}$; head pale yellowish, scales from neck to insertion of antennae with grey tips; labial palpi on inside pale yellowish too, on outside dark grey; scape of antenna with pecten of some bristles, flagellum more or less ringed; thorax and tegulae pale yellowish, basally overlaid with dark grey scales; forewing on dorsum with four tufts of raised scales, the largest at $1 / 3$ and at $1 / 2$, the smallest at $2 / 3$ and at $3 / 4$; the pattern is colourful: in the middle three minute black dots at $1 / 3,1 / 2$, and $3 / 4$, bordered to costa by whitish line; between the dots each a golden-brown area, two additional golden-brown patches between third dot and apex; basal third of wing pale yellowish, interrupted by an angle-shaped darker brown stripe from costa to dorsum; a small whitish thin wedge-shaped stripe from dorsum before second tuft oblique to the second black dot, the last golden-brown patch before apex with pale line to apex; the other area (costa from base to apex, area on dorsum from first tuft to apex) dark grey, fringe below apex with two dark scale-lines; hindwing grey.

Male genitalia (Figs 39-41): Uncus slender, with pointed tip, tegumen mid-dorsally and at proximal and lateral edges strong sclerotised; valva as long as uncus-tegumen, ampulla stout, nearly straight, upper edge strong sclerotised, ending in a small pointed tip, border to valva strong sclerotised, cucullus nearly two times longer than ampulla, sacculus with narrow pointed tip below border 
of ampulla; phallus appr. $2 / 3$ of the length of valva, without cornutus.

Female genitalia (Figs 42-45): Proximal edge of segment VIII truncated, laterally rounded, laterally each a oval stronger sclerotised area, ostium calyx-shaped, lateral edges stronger sclerotised, corpus bursae with a broad band of minute sclerotisations, signum hook-shaped, the shape is variable.

Remarks: Superficially surely distinguishable from malawica by having a clolourful pattern on forewing, while malawica on forewing with a large dark area on costa from $1 / 2$ to $2 / 3$, extending to cell. In the genitalia structure are some similarities, but, paramalawica with quite shorter phallus without cornutus, and female with calyx-shaped ostium and corpus bursae more covered by sclerotisations.

\section{Epermenia (Calotripis) karurucola sp. n.}

Holotype $\sigma^{\star}$, "Coll. Museum Tervuren, Kenya: Aberdares Nat. Park 12/4/2000, Karuru Falls, 2980 m, 00²2'S, 36 54'E (N6), [leg.] Ugo Dall'Asta;" “RMCA ENT 000003210;" "Gen.präp. [genitalia slide] Gaedike Nr. 7058;" "Holotypus ơ Epermenia karurucola sp. n. det. R. Gaedike 2011;” RMCA.

Derivatio nominis: Named after the location of the holotype.

Diagnosis (Fig. 5): Wingspan $12 \mathrm{~mm}$; head shining pale yellowish, labial palpi with same colouration, outside with some darker scales; scape of antenna with pecten, flagellum ringed; thorax and tegulae pale yellowish, basally grey; forewing on dorsum with three tufts of raised scales, at $1 / 4$ and $1 / 2$, at $2 / 3$ the third only as indication; as the condition of the holotype is somewhat poor, only parts of pattern are visible: in the middle at $1 / 2$, after $1 / 2$ and at $2 / 3$ each a minute black dot, surrounded by white; the basal third light yellowish, the area from first to third dot dark grey with some brown patches, before apex a dark brown patch; hindwing light grey.

Male genitalia (Figs 46-48): Uncus slender, curved, with pointed tip, tegumen without stronger sclerotised margins; valva as long as uncus-tegumen, ampulla stout, curved, with pointed tip, upper edge without stronger sclerotisation, border to valva strong sclerotised, cucullus a little longer than ampulla, sacculus with small pointed tip below border of ampulla; phallus a little more than a half of the lenght of valva, basally rounded, in the middle narrower, without cornutus.

Female genitalia: Unknown.
Remarks: In the shape of genitalia similar to the species malawica, paramalawica and formosa, but ampulla without stronger sclerotised upper edge.

Epermenia (Calotripis) formosa sp. n.

Holotype $0^{*}$, "Kenya Central Castle Forest Lodge, $2000 \mathrm{~m}, 0^{\circ} 22^{\prime} 51^{\prime \prime S}, 37^{\circ} 18^{\prime} 35^{\prime \prime E}$, 6.xii.2010, [leg.] D. Agassiz \& L. Aarvik;" "Gen.präp. [genitalia slide] Gaedike Nr. 7809;" "Holotypus o Epermenia formosa sp. n. det. R. Gaedike 2012;” BMNH.

Etymology: The name refers to the beauitful view [latin: formosa = beautiful]

Diagnosis (Fig. 6): Wingspan $13 \mathrm{~mm}$; head cream; antenna dark grey to black, scape at underside cream, with pecten, flagellum ringed; labial palpi inside cream, outside dark grey, apices of segments cream; thorax cream, tegulae dark grey, apically cream; forewing on dorsum at $1 / 3$ and $1 / 2$ each with tuft of raised scales, at $2 / 3$ and $3 / 4$ indications of additional two minute tufts; on whitish to cream ground colour a light brown and blackish pattern: in the middle at $1 / 3,1 / 2$ and $2 / 3$ a minute black dot, surrounded by nearly white area; from costa to cell between $1 / 3$ and $2 / 3$ a blackish area, oblique prolonged to first tuft; on costa numerous very short dark stripes from base to blackish area; blackish are a smaller patch on dorsum at $3 / 4$, the apex and some short stripes on costa at the last third; area above the patch on dorsum, and cell below the blackish area are light brown, basal forth is light brown too; hindwing shining light grey.

Male genitalia (Figs 49-51): Uncus curved, with pointed tip, basally with short bristles; tegumen mid-dorsally and laterally with stronger sclerotised margin; valva as long as uncus-tegumen, ampulla stout, nearly straight, upper edge somewhat stronger sclerotised, tip divided into two short pointed teeth, border to valva strong sclerotised, cucullus protruding ampulla, sacculus with stronger sclerotised pointed tip below border of ampulla; phallus $1 / 2$ of the lenght of valva, narrow, with thin cornutus, appr. $2 / 3$ of lenght of phallus.

\section{Female genitalia: Unknown.}

Remarks: The colourful pattern distinguishes the new species from the other species with similar shape of genitalia (malawica, paramalawica, karurucola); the tip of ampulla with the two pointed teeth is characteristic, too. 
Epermenia (Calotripis) dallastai sp. n.

Holotype ${ }^{\top}$, "Coll. Museum Tervuren, Kenya: Taita Hills, 29/06/1998 (H3), Mbololo Forest, [leg.] U. Dall'Asta;" "RMCA ENT 000003212;" "Holotypus ơ Epermenia dallastai sp. n. det. R. Gaedike 2011;” RMCA.

Paratypes: $60^{\circ}, 3$, same data as holotype, "RMCA ENT 000003213; 000003216; 000003217; 000003223; 000003228; 000003229; 000003230; 000003235;

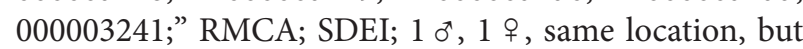
25/06/1998 (E3), "RMCA ENT 000003218; 000003234;" RMCA; SDEI; $20^{\star}, 1$ ㅇ, "Coll. Museum Tervuren, Kenya: Taita Hills, 30/06/1998 (I3), Mbololo Forest Edge, [leg.] U. Dall'Asta;" "RMCA ENT 000003219; 000003226; 000003227;" RMCA; SDEI; 1 o", "Coll. Museum Tervuren, Kenya: Taita Hills, 04/07/1998 (M3), Ngangao Forest Edge, [leg.] U. Dall'Asta;" "RMCA ENT 000003222; RMCA; $20^{\star}, 1$ 우 "Coll. Museum Tervuren, Kenya: Taita Hills, 05/07/1998, (N3), Ngangao Forest, [leg.] U. Dall'Asta;" "RMCA ENT 000003220; 000003225; 000003232; RMCA; SDEI; $10^{\star}, 1$ †, "Coll. Museum Tervuren, Kenya: Taita Hills, 06/07/1998, (O3), Ngangao For. \& Plant., [leg.] U. Dall'Asta;" "RMCA ENT 00000331; 00000333; RMCA; 1 o, "Coll. Museum Tervuren, Kenya: Taita Hills, 08/03/1999, (F4), Mbololo indig. forest, [leg.] U. Dall'Asta Hg+Hal.;" "RMCA ENT 00000352; RMCA; $4 \sigma^{\top}, 5$ \% , "Coll. Museum Tervuren, Kenya: Taita Hills, 11/08/1999, (H5), Mbololo indig. forest, [leg.] U. Dall'Asta Hg+Hal.;" "RMCA ENT 00000336; 00000337; 00000338; 00000339; 00000340; 00000342; 00000343; 00000344; 00000345; RMCA; SDEI.

Derivatio nominis: Named after my colleague, Ugo Dall'Asta, the collector of this new species.

Diagnosis (Fig. 7): Wingspan 12 - $13 \mathrm{~mm}$; head dark greybrown, labial palpi, antenna (scape with pecten of some scales), thorax and tegulae with the same colouration; forewing on dorsum with two tufts of raised scales, the first large, from $1 / 4$ to before $1 / 2$, the second after $1 / 2$, in the last fourth indications of two additional tufts; ground colour of wing brown, basal third somewhat dark grey; in the middle, at $1 / 3$ and at $2 / 3$ each a minute black dot, immediatly before apex a dark brown patch, from apex on fringe two dark scale lines; on dorsum, at beginning of first tuft a whitish stripe oblique to cell, at beginning of the second tuft a small whitish patch; hindwing shining grey.

Male genitalia (Figs 52-55): Uncus long, nearly straight; tegumen narrow triangular, mid-dorsally with a rodshaped sclerotisation, valva as long as uncus-tegumen, narrow, ampulla straight, slender, with rounded tip, border to valva with only a thin strong sclerotisation, cucullus longer than ampulla, sacculus with prolonged thin, pionted tip below border of ampulla; phallus a little shorter than valva, straight, vesica with rod-shaped cornuti, the variable view depends from preparation.
Female genitalia (Figs 56-57): Proximal edge of segment VIII invaginated in the middle, ostium stronger sclerotised, below it, at beginning of ductus bursae, an ellyptical sclerotisation, covered by minute sclerotised thorns, corpus bursae around signum also with minute scale-shaped sclerotisations, signum finger-shaped, with rounded tip, basally a strong sclerotised edge.

Remarks: The shape of male genitalia (triangular tegumen with rod-shaped sclerotisation and the narrow valva with straight ampulla) is characteristic for this new species.

\section{Epermenia (Calotripis) costomaculata sp. n.}

Holotype 0", "Kenya: Central Naro Moru, 1960 m, $0^{\circ} 9^{\prime} 5 " \mathrm{~S}, 37^{\circ} 0^{\prime} 40 " \mathrm{E}$, 2.xii.2008, [leg.] D. Agassiz, L. Aarvik \& A. J. Kingston; "Holotypus ơ Epermenia costamaculata sp. n. det. R. Gaedike 2012;” NMK.

Paratypes: $1 \sigma^{\top}$, same dates as holotype; coll. Agassiz; $10^{\circ}$, "Kenya: Rift Valley, Gilgil $2100 \mathrm{~m}, 0^{\circ} 29^{\prime} \mathrm{S} 36^{\circ} 23^{\prime} \mathrm{E}$, 29.x.2003, [leg.] D. J. L. Agassiz;" SDEI.

Derivatio nominis: The name refers to the characteristic pattern on forewing.

Diagnosis (Fig. 8): Wingspan 13 - $14 \mathrm{~mm}$; head cream mixed with grey; labial palpi inside cream, outside overlaid with grey scales, last segment complete greyish; scape of antenna with same colouration as head, flagellum light ringed; thorax and tegulae cream, basally somewhat darker, forewing on dorsum with three tufts of raised scales at 1/3,1/2 and 2/3; on costa, opposite the first tuft, a light cream patch, reaching cell, the other wing area covered by dark brown, brown, and dark grey scales without clear pattern, only the dark brown scales forms in the middle a row of four patches; hindwing shining grey.

Male genitalia (Figs 58-60): Uncus slightly curved, tegumen mid-dorsally and at basal margin stronger sclerotised, valva larger than uncus-tegumen, broadest basally, costa became narrower from transtilla to curved ampulla, border to valva strong sclerotised, cucullus more or less narrow, with rounded tip, somewhat longer than ampulla, sacculus only with indication of stronger sclerotised tip below border of ampulla; phallus shorter than valva, straight, without cornutus.

Female genitalia: Unknown.

Remarks: The pattern of forewing with the light cream patch is characteristic for the species. 
Epermenia (Calotripis) turicola sp. n.

Holotype o", "Kenya: Rift Valley, Prov. Turi, $8000 \mathrm{ft}$, 15.x.1998, [leg.] D. J. L. Agassiz;" "Holotypus ơ Epermenia turicola sp. n. det. R. Gaedike 2011;” NMK.

Paratypes: 1 ㅇ, same location as holotype, same collector, but 26.i.1999; coll. Agassiz; 1 o", "Kenya Western Kericho, 7000 ft, 31.viii.1999, [leg.] D. J. L. Agassiz;" SDEI; 1 \%, "Tanzania, Iringa Reg., Makete Distr.: Kiitulo Plateau N. 2700 m, 29.xi.-1.xii.2005, [leg.] L. Aarvik, M. Fibiger, A. Kingston;" NHMO.

Derivatio nominis: Named after the province Turu, the location of the holotype.

Diagnosis (Figs 9-10): Wingspan 17 - $22 \mathrm{~mm}$; head brown, in the middle from neck to labial palpi more or less golden brown; labial palpi inside cream-coloured, outside dark brown, long, curved; antenna dark brown, scape with pecten of some scales; thorax and tegulae dark brown, apically cream-coloured; forewing on dorsum with three tufts of raised scales at $1 / 3,1 / 2$ and $2 / 3$; in the middle of wing opposite the three tufts each a minute black dot, surrounded by white ring, the second dot somewhat prolonged, the third dot prolonged oblique upward, the white ring prolonged nearly to costa; from black apex two sickle-shaped dark scale lines on fringe, nearly the whole other wing dark brown, mixed with dark grey, costa with numerous very short lighter stripes; sometimes forewing more or less unicoloured brown, the three dots with the white rings clear visible (see fig. 10); hindwing shining light grey.

Male genitalia (Figs 61-63): Uncus curved; tegumen somewhat elongated, proximal margin stronger sclerotised; valva elongated, more or less parallesided, ampulla nearly straight, border to valva strong sclerotised, cucullus a little longer than ampulla, sacculus ends in a strong sclerotised tooth below border of ampulla, phallus a little more than $1 / 2$ of the lenght of valva, slightly curved, cornutus narrow, with rounded tip, $1 / 3$ of the lenght of phallus.

Female genitalia (Figs 64-65): Proximal edge of segment VIII truncated, laterally each a oval sclerotisation, ostium stronger sclerotised, corpus bursae covered with minute scale-shaped sclerotisations, signum small, basal margin strong sclerotised, narrower to rounded tip.

Remarks: The large size and the pattern of forewing with the black dots surrounded by white and the oblique white prolongations are characteristic for this species.

Epermenia (Calotripis) hamata sp. n.

Holotype ơ, "RSA, West-Natal, Dragon Peaks Park, 9.-12. xi.1993, leg. Mey \& Ebert;" “Gen.präp. [genitalia slide]

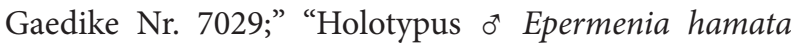
sp. n. det. R. Gaedike 2011;” ZMHB.

Derivatio nominis: The name refers to the hook-shaped cornutus [latin: hamatus $=$ hook-shaped].

Diagnosis (Fig. 11): Wingspan $12 \mathrm{~mm}$; head grey, laterally, arround the eyes, nearly black; scape of antenna dark grey, with pecten, flagellum ringed; labial palpi inside grey, outside darker; thorax and tegulae dark grey, tip of thorax black; forewing on dorsum with tufts of raised scales, two of them, at $1 / 4$ and $1 / 2$ are nearly invisible because of poor condition, the others at $2 / 3$ and $3 / 4$; in the middle of wing at $1 / 3$ and $2 / 3$ each a minute black dot, partly bordered by white line; wing between these dots black; black are also a patch below base to dorsum, an oblique stripe at $1 / 4$ from costa to dorsum, a patch on costa at $3 / 4$, and a minute dot on apex; the other parts of wing dark grey; from base to apex three brown thin lines; hindwing light grey.

Male genitalia (Figs 66-68): Uncus slender, curved; tegumen with strong sclerotised basal and proximal margins; valva longer than uncus-tegumen, stout, costa at $2 / 3$ vaulted, than became abruptly narrower to short, straight ampulla, border to valva only a little stronger sclerotised, cucullus as long as ampulla, sacculus with pointed tip, proximal edge stronger sclerotised, phallus somewhat shorter than valva, straight, with two cornuti, the first appr. 1/2 of lenght of phallus, more or less parallelsided, the second, two times shorter than the first, basally rounded, with hook-shaped tip.

Female genitalia: Unknown.

Remarks: The black pattern of forewing, the shape of valva with vaulted costa and short ampulla and the hook-shaped cornutus are characteristic for this species.

\section{Epermenia (Calotripis) aarviki sp. n}

Holotype ơ, "Tanzania, Morogoro Distr. \& Town, 550600 m, 25.iii.1992, leg. L. Aarvik;" "Gen.präp. [genitalia slide] Gaedike Nr. 7034;" "Holotypus o Epermenia aarviki sp. n. det. R. Gaedike 2011;” NHMO.

Paratypes: 1 ㅇ, "Kenya Coast Kilifi, s. 1., 8.iv.1999, [leg.] D. J. L. Agassiz;" coll. Agassiz; 1 ㅇ, "Kenya, Arabuko Sokoke Forest, $8 \mathrm{~km}$ W Gede, 70m, 03 $17^{\prime} \mathrm{S} 039^{\circ} 50 \mathrm{E}$, leg. J. \& W. De Prins;" "RMCA ENT 000003200"; RMCA.

Derivatio nominis: Named after my colleague Leif Aarvik, the collector of the holotype.

Diagnosis (Fig. 12): Wingspan 7 - $8 \mathrm{~mm}$; head, antenna, labial palpi, thorax and tegulae dark grey, tips of scales 
lighter; forewing on dorsum at $1 / 3,1 / 2,2 / 3,3 / 4$ each with tuft of raised scales, the first two the largest; in the middle of wing at $1 / 3$ and $2 / 3$ each a minute black dot, wing from the base to the first dot dark grey, a patch around the second dot and the area before apex with same colouration, wing between the two dots and above fourth tuft golden-brown; hindwing light grey.

Male genitalia (Figs 69-72): Uncus slightly curved, slender, with pointed tip; tegumen triangular; vinculum broad, narrowest in the middle; valva from broad base narrower to apex, ampulla straight, narrow, no strong sclerotised border to valva, on the inside of valva a triangular fold; cucullus oval, sacculus prolonged as thin tip into the cucullus; phallus appr. 1/2 of the lenght of valva, basally rounded, narrower to apex, cornutus nearly as long as phallus, slender, with pointed tip.

Female genitalia (Figs 73-74): Proximal edge of segment VIII truncated with rounded angles, area around ostium and laterally with shorter wrinkled sclerotisations; ductus bursae with a strong sclerotised band; corpus bursae partly covered with minute scale-shaped sclerotisations, signum small, triangular.

Remarks: The small size and the very large two first tufts, in the male genitalia the broad vinculum, the shape of valva and the long slender cornutus, in the female genitalia the wrinkles on segment VIII are characteristic for this species.

\section{Epermenia (Calotripis) ruwenzorica sp. $\mathrm{n}$.}

Holotype o", "Congo Belge: P.N.A. 1-2-x-1952, [leg.] P. Vanschuytbroeck \& J. Kekenbosch 1290;" "Masif Ruwenzori, Kiondo, 4.210 m, dans lobélle;" "RMCA ENT 000003253;" "Gen.präp. [genitalia slide] Gaedike Nr. 7057;" "Holotypus o Epermenia ruwenzorica sp. n. det. R. Gaedike 2011;” RMCA.

Derivatio nominis: Named after the "Masif Ruwenzori", the location of the holotype.

Diagnosis (Fig. 13): The specimen is in poor condition, the pattern of forewing is only partly visible. Wingspan $17 \mathrm{~mm}$; head (partly rubbed), antenna, labial palpi, thorax and tegulae dark greybrown, palpi inside lighter; forewing greybrown, in the middle of wing at $1 / 3$ and $2 / 3$ each a minute black dot, at $1 / 2$ from dorsum to the second dot an oblique thin whitish line, before apex a short brown stripe; on dorsum are visible only indications of tufts of raised scales at $1 / 3$ and $1 / 2$; hindwing browngrey.

Male genitalia (Figs 75-77): Uncus stout, with pointed tip; tegumen without strong sclerotised edges; valva clear longer than uncus-tegumen, ampulla curved, with pointed tip, border to valva strong sclerotised, cucullus only a little longer than ampulla, more or less triangular, sacculus ends with narrow prolonged sclerotisation below border of ampulla; phallus as long as valva, basally rounded, apically truncated, cornutus $2 / 3$ of the lenght of phallus, base pointed, apex rounded.

\section{Female genitalia: Unknown.}

Biology: The specimen was collected "dans lobélle".

Remarks: Superficially similar to turicola, but in the male genitalia the stout uncus, the curved ampulla, and the large cornutus are characteristic for this species.

Epermenia (Calotripis) bulbosa GAEDIKE, 2004

Kenya: 1 , Aberdares Nat. Park Ruhuruini Gate 2/04/2000, Camp site $2334 \mathrm{~m}, 00^{\circ} 23^{\prime} \mathrm{S}, 36^{\circ} 49^{\prime} \mathrm{E}$ (G6), leg. Ugo Dall'Asta; RMCA ENT 000003251; RMCA; 1 \% , near Nairobi, 28/08/1999 (V5), Olulula forest, U. Dall'Asta Hg + Hal.; RMCA ENT 000003250; RMCA.

New country record, hitherto known only from type location (RSA).

The examined material make it possible to describe the female genitalia for the first time (figs 78-79): Proximal edge of segment VIII rounded, ostium and first part of ductus bursae stronger sclerotised, signum small, oval, with pointed tip and with longitudinal keel.

\section{Epermenia (Calotripis) tenuipennella sp. $\mathrm{n}$.}

Holotype \& "Kenya, Central Province, Naro Moru 1950 m, 37MBV 7864 8327, 1.-5.xii.2008, [leg.] L. Aarvik, D. Agassiz, A. Kingston;" "Gen.präp. [genitalia slide] Gaedike Nr. 7625;" "Holotypus + Epermenia tenuipennella sp. n. det. R. Gaedike 2012;” NHMO.

Paratypes: 1 ㅇ, "Kenya Central Naro Moru, $6500 \mathrm{ft}$, 28.xii.1999, [leg.] D. J. L. Agassiz;” coll. Agassiz; 1 ㅇ, "Coll. Museum Tervuren, Kenya: Taita Hills, 29/06/1998 (H3), Mbololo Forest, [leg.] U. Dall'Asta;" "RMCA ENT $000003209 ; "$ RMCA.

Derivatio nominis: Named after the very narrow shape of forewings.

Diagnosis (Fig. 14): Wingspan 11 - $12 \mathrm{~mm}$; head grey, neck and laterally dark grey; scape of antenna dark grey, flagellum somewhat ringed, labial palpi inside whitish, outside dark grey; thorax and tegulae dark grey; forewing narrow, on dorsum at $1 / 3,1 / 2,2 / 3$ and before $3 / 4$ each a tuft of raised scales, the first two are larger than the other two; in the middle of wing before $1 / 2$ and at $3 / 4$ each a 
minute black dot; on costa, between $1 / 3$ and $1 / 2$ a whitish patch, reaching cell and the first black dot, overlaid by grey scales; a small whitish patch on costa before apex; from base two thin brown lines, the first to costa at $1 / 2$, the second to dorsum at fourth tuft, brown are the area between the two dots and a lence-shaped patch before apex, hindwing light grey.

Male genitalia: Unknown.

Female genitalia (Fig. 80): proximal edge of segment VIII rounded, along $2 / 3$ of the lenght of ductus bursae a rod-shaped sclerotisation, last part of ductus somewhat larger, covered with minute scale-shaped sclerotisations, signum narrow, slightly sickle-shaped, with pointed tip, proximal half on outside with strong sclerotised edge.

Remarks: Superficially characteristic by the narrow wings, female genitalia similar to agassizi, but the proximal edge of segment VIII is not invaginated, and the rodshaped sclerotisation is clear broader.

Epermenia (Epermenia s. str.) agassizi sp. $\mathrm{n}$.

Holotype o", "Kenya Rift Valley, Turi, 8000 ft, 2.iii.2000, [leg.] D.J.L. Agassiz;" "Gen.präp. [genitalia slide] Gaedike Nr. 7004;" "Holotypus ơ Epermenia agassizi sp. n. det. R. Gaedike 2011;” NMK.

Paratypes: 3 , same location, but 22., 25.v.1999, 28.ii. 2000; coll. Agassiz; SDEI; 1 + , Kenya: Central Castle Forest Lodge, $2060 \mathrm{~m}, 0^{\circ} 22^{\prime} 51^{\prime \prime S}, 36^{\circ} 18^{\prime} 35^{\prime \prime} \mathrm{E}, 20 . x i .2009$, [leg. D. J. L. Agassiz; coll. Agassiz; $10^{\star}$ "Coll. Museum Tervuren, Kenya: Taita Hills Ngangao, 29/II/2000 Camp. Site $03^{\circ} 22^{\prime} \mathrm{S} 38^{\circ} 20^{\prime} \mathrm{E}$ (H7) [leg.] Ugo Dall'Asta;" "RMCA ENT 000003214;" 1 o $^{\star}$, Coll. Mus. Tervuren Kenya Nairobi, Gatamaiyu Natural Reserve 00 $58^{\prime} \mathrm{S} 036^{\circ} 41^{\prime} \mathrm{E}, 2285 \mathrm{~m}$, 24.x.2001, leg. J. De Prins;" "RMCA ENT 000003204;" SDEI; 1 \% , Kenya Gatamaiyu Natural Reserve $00^{\circ} 58^{\prime} S$ 036²41'E, 2305 m, 24.iv.2002, leg. J. De Prins;" "RMCA ENT 000003203;" RMCA; 1 Kenya Kakamega Forest 1590 m, 00²21'S 03451'E, 28.iii.2003, leg. J. De Prins;" RMCA.

Derivatio nominis: Named after my colleague David Agassiz, the collector of the holotype of this species and of other important material of Afrotropical Epermeniidae.

Diagnosis (Fig. 15): Wingspan $8-11 \mathrm{~mm}$; head creamgrey, laterally darker; antenna dark grey, flagellum ringed; labial palpi dark grey, tips of segments whitish; thorax and tegulae dark cream, basally dark grey; forewing on dorsum at $1 / 4,1 / 2,2 / 3$ and $3 / 4$ each with tuft of raised scales, the first tuft is the largest, the third and the fourth only as indication visible; in the middle of wing at $1 / 3$ and at 3/4 each a minute black dot, the area between the dots golden brown, the same colouration has a patch proximal the second dot; on costa before apex a small yellowish patch, wing from base along costa to this patch dark grey, apex black, on the first half of fringe two black scale-lines; hindwing grey.

Male genitalia (Figs 81-82): Uncus slender, curved, with pointed tip; tegumen with strong sclerotised proximal edge; vinculum somewhat triangular, basal edge strong sclerotised; valva longer than uncus-tegumen, ampulla straight, without visible border to valva, situated over the costal edge of cucullus, cucullus oval, apically rounded, sacculus basally with a short bristled finger-like prolongation; phallus nearly as long as valva, basally broader, straight, cornutus appr. $1 / 3$ of the lenght of phallus, base forked, proximal rounded.

Female genitalia (Figs 83-85): Proximal edge of segment VIII rounded, invaginated at ostium, ductus bursae with a thin rod-shaped sclerotisation, signum more or less elliptical, the shape somewhat variable.

Remarks: Differences to tenuipennella see under this species.

\section{Epermenia (Cataplectica) kenyacola sp. n.}

Holotype ơ, "Kenya Rift Valley, Turi, 8000 ft, 22.x.1998, [leg.] D. J. L. Agassiz;" "Holotypus o Epermenia kenyacola sp. n. det. R. Gaedike 2011;” NMK.

Paratypes: $30^{-1}, 2$ ㅇ, same location as holotype, but 5.xi., 6.xii., 11.xii.1998; 14.v.1999; 21.i.2000; NMK; coll. Agassiz; SDEI; 1 o", "Kenya Western Pr. Kericho, $7000 \mathrm{ft}$, 31.x.1998, [leg.] D. J. L. Agassiz;” coll. Agassiz; 1 o $^{\star}$, “Coll. Museum Tervuren, Kenya Aberdare National Park Ruhuruini Gates, $2300 \mathrm{~m}, 00^{\circ} 23^{\prime} \mathrm{S}, 036^{\circ} 49^{\prime} \mathrm{E}$, leg. J. De Prins;" "RMCA ENT 000003193;" RMCA; 1 ㅇ, "Coll. Museum Tervuren, Kenya: Aberdares National Park Ruhuruini Gate, 3/4/2000, Electric fence alt $2334 \mathrm{~m}, 00^{\circ} 23^{\prime} \mathrm{S}, 36^{\circ} 49^{\prime} \mathrm{E}$, (H6), [leg.] Ugo Dall'Asta;" "RMCA ENT 000003207;" RMCA; 1 o", "Malawi Central Region, Lilongwe District: Ntchisi Forest Reserve, 1560 m, 19.ii.2004, leg. L. Aarvik;" NHMO; 1 o*, "Ht. Katanga, Tshinkolagwe, 6.7.[19]31, [leg.] J. Romieux;" MHNG.

Derivatio nominis: Named after the country, in which was collected the holotype.

Diagnosis (Figs 16-17): Wingspan 10 - $12 \mathrm{~mm}$; head pale yellowish, antenna dark grey, underside whitish, scape with distinct pecten, labial palpi on inside whitish, on outside dark grey; thorax and tegulae pale yellowish, basally overlaid with grey scales; forewing on dorsum at $1 / 3,1 / 2$ each with tuft of raised scales, at $2 / 3$ an indication of a third tuft, wing colouration pale yellowish, in the middle of wing at $1 / 3$ and at $3 / 4$ each a minute black dot; costa from base to apex, and dorsum from first tuft to 
apex each with a stripe of grey scales, from second black dot to apex light brown, fringe with two black scale lines; hindwing grey. Some specimens more yellowish and light brown.

Male genitalia (Figs 86-88): Uncus below base broadest, apical truncated, tegumen with strong sclerotised proximal edge; valva as long as uncus-tegumen, ampulla curved, with pointed tip, border to valva strong sclerotised, cucullus a little protruding ampulla, cucullus with upward directed pointed, strong sclerotised end below border of ampulla; phallus a little longer than phallus, straight, without cornutus.

Female genitalia (Fig. 89): Proximal edge of segment VIII slightly immersed at ostium, ostium laterally with strong sclerotised margin, corpus bursae without signa.

Remarks: The pale yellowish colouration of forewing and in male genitalia the slender uncus and the phallus without cornutus are characteristic for this species in comparison to mineti and triacuta.

\section{Epermenia (Cataplectica) triacuta sp. n.}

Holotype $0^{\star}$, "Namibia, Vananto, Otavi Mountains, 29. 31.iii.2003, leg. W. Mey;" “Gen.präp. [genitalia slide] Gaedike Nr. 7031;" "Holotypus ơ Epermenia triacuta sp. n. det. R. Gaedike 2011;” ZMHB.

Derivatio nominis: The name refers to the shape of cornutus with three pointed tips.

Diagnosis (Fig. 18): Wingspan $10 \mathrm{~mm}$; head light cream, laterally with some grey scales, scape grey, with pecten, underside whitish, flagellum ringed; thorax and tegulae cream, basally overlaid with some dark grey scales; ground colouration of forewing cream, on dorsum at $1 / 3$, $1 / 2$ and $2 / 3$ each a tuft of raised scales, in the middle of wing at $1 / 3$ and at $3 / 4$ each a minute black dot, the first only as indication; from first tuft a light brown stripe, oblique reaching costa at $1 / 2$, apically the second black dot and on apex each a brown patch; from apex on fringe two black scale lines; the ground colouration with scattered dark grey scales, some more of them along costa; hindwing shining light grey.

Male genitalia (Figs 90-92): Uncus with broad base, than narrower, tip rounded; tegumen with strong sclerotised proximal edge; valva longer than uncus-tegumen, ampulla curved, with pointed tip, protruding cucullus, border to valva only indicated, cucullus with thin, pointed tip below border of ampulla; phallus as long as valva, cornutus somewhat shorter than phallus, with three pointed tips.

Female genitalia: Unknown.
Remarks: The brown pattern on forewing and the cornutus with three tips are characteristic for this species. Superficially similar to iniquella, but in male genitalia the broad uncus and the shape of cornutus are different.

\section{Epermenia (Cataplectica) iniquella (Wocke, 1867)}

Kenya: 1 \% , Rift Valley, Gilgil 2100 m, $0^{\circ} 37^{\prime} \mathrm{N}, 36^{\circ} 22^{\prime} \mathrm{E}$, 6.xii.2010, leg. D. Agassiz \& L. Aarvik; coll. Agassiz.

This is the second record of this species from Afrotropical Region after the first record from South Africa (Holotype of Epermenia ochrodesma MEYRICK, 1913) (GAEDIKE, 2004).

\section{Gnathifera punctata sp. n.}

Holotype ơ: "RSA, North. Cape, Kamieskroon, Farm Windhoek, 16.x.2007, leg. W. Mey;" "Campsite, Automat. Falle [automatic trap]"; "Holotype o Gnathifera punctata sp. n. det. R. Gaedike 2011;” ZMHB.

Paratypes: same data as holotype: 10 , "Gen.präp. [genitalia slide] Gaedike Nr. 7528;" SDEI; 1 우, same location as holotype, "Bachtal ca. $2 \mathrm{~km}$ oberh. Farmhaus [stream valley, appr. $2 \mathrm{~km}$ above farm house];" "Gen.präp. [genitalia slide] Gaedike Nr. 7527;” ZMHB.

Derivatio nominis: The name refers to the pattern of the forewing.

Diagnosis (Fig. 19): Wingspan 11 - $12 \mathrm{~mm}$; head yellowish; antenna dark grey, lapbial palpi dark grey, inside whitish; thorax and tegulae dark grey; forewing on dorsum at before and after $1 / 2$ each with a small tuft of raised scales; in the middle of wing at $1 / 2,1 / 2$ and $2 / 3$ each a small black dot, two other black dots on costa before apex; a narrow golden brown stripe from first black dot to apex, interrupted by the black dots; the apical half of wing more or less complete overlaid by dark grey and blackish scales; hindwing light grey.

Male genitalia (Figs 93-95): Uncus laterally each with bristled, pointed process, apical in the middle bulged, with rounded lateral edges; tegumen mid-medial and along basal and proximal edges stronger sclerotised; valva as long as uncus-tegumen, narrow, apical rounded, along the whole valva a fold (cucullus?), ending in a short strong sclerotised tooth; phallus as long as valva, parallelsided, vesica with numerous small slender pointed thorns.

Female genitalia (Fig. 96): Proximal edge of segment VIII truncated, anterior apophysae forked, ventral branches ends in a stronger sclerotised area, covered with minute lunt thorns, in the middle immersed to ostium, nearly the 
whole ductus bursae covered with minute blunt thorns too, at beginning of corpus bursae a sclerotised ring.

Remarks: The pattern of the black dots make the species superficially distinguishalbe from the other afrotropical members of Gnathifera, in male genitalia the shape of uncus is characteristic, too.

\section{Ochromolopis sagittella sp. $\mathrm{n}$}

Holotype $\sigma^{\star}$, "Kenya: Rift Valley, Prov. Turi, $8000 \mathrm{ft}$ 13.xii.1998, [leg.] D. J. L. Agassiz;" "Holotypus o Ochromolopis sagittella sp. n. det. R. Gaedike 2011;" NMK.

Paratypes: $50^{\star}$, same location as holotype, same collector, but 26.xi.1998; 4.v.1999; 12.v.1999; 22.v.1999; 26.v.1999; 4.xi.1999; NMK; coll. Agassiz; SDEI; 1 o $^{\text {* }}$ "Kenya Rift Valley, Gilgil, 0³2'S 36²2'E, [leg.] D. J. L. Agassiz;" SDEI.

Derivatio nominis: Named after the shape of phallus [latin "sagitta" = "arrow"]

Diagnosis (Fig. 20): Wingspan 12 - $14 \mathrm{~mm}$; head, labial palpi, thorax and tegulae light clay-coloured, the outside of palpi with grey scales; scape with pecten and flagellum dark grey, tegulae basally dark grey too; forewing light clay-coloured, without pattern; in the middle of wing at $1 / 3,1 / 2$ and $2 / 3$ each a minute black dot, a forth dot between the first and second dot nearby the dorsum; apex surrounded by dark grey, nearly black scales, prolonged on fringe as two scale-lines, dorsum without tufts of raised scales on dorsum; hindwing light grey.

Male genitalia (Figs 97-101): Uncus stout, parallelsided, with rounded tip; tegumen with strong sclerotised basal, proximal and mid-medial margins, gnathos without thorns, valva only somewhat longer than uncus, costal arm various, on right valva more or less parallelsided, on left valva basal slender, apical half broadered, basal part of both valvae longitudinally folded, with rounded bristled tip; phallus longer than valva, light curved, one side strong sclerotised, the pointed tip arrowhead-shaped, vesica with minute thin thorns.

Female genitalia: Unknown.

Remarks: The various shape of valvae is characteristi for this species.

Ochromolopis cana sp. n.

Holotype o': "RSA, Stellenbosch, Jonkershoek, $185 \mathrm{~m}$, 26.9.-3.10.2006, leg. W. Mey LF [light];" "Glenconner Cott., aut. Falle [trap];" "Gen.präp. [genitalia slide] Gaedike Nr. 7526;" "Holotypus o Ochromolopis cana sp. n. det. R. Gaedike 2011;" ZMHB.
Paratype: 1 ㅇ, same data as holotype; “Gen.präp. [genitalia slide] Gaedike Nr. 7534;” ZMHB.

Derivatio nominis: Named after the main colouration [latin: "canus" = grey].

Diagnosis (Fig. 21): Wingspan 12 - $13 \mathrm{~mm}$; head and labial palpi light grey, outside of palpi darker; antenna grey, flagellum ringed; thorax and tegulae dark grey; forewing grey, with a somewhat indifferent dark grey pattern. Dark grey are two oblique short stripes at $1 / 4$ and $1 / 2$ on dorsum to cell, and the last forth of wing; on dorsum, at $1 / 2$ and $2 / 3$ each indication of tufts of raised scales; hindwing light grey.

Male genitalia (Figs 102-104): Uncus from broad base narrower to tip with two rounded angles, subapically with a calyx-shaped process; tegumen with rounded lateral angles with minute thorns, basally, proximally and mid-medial with strong sclerotised margins; valva somewhat longer than tegumen, costal arm longer than cucullus, with rounded tip and with more or less triangular process at $1 / 2$, cucullus ends in a directed upwards pointed tip; phallus appr. 1.5 times longer than valva, curved, the concave side strong sclerotised, basally narrow, in the middle broader, subapically thin, ending into a triangular tip, versica covered with minute strong sclerotised thorns.

Female genitalia (Fig. 105): Anterior apophysae forked, ventral branches ends into large elongated plates, connected in the middle, armed with minute thin thorns; first part of ostium with stronger sclerotised margins.

Remarks:The shape of uncus and tegumen and the large phallus are characteristic for this species and are distinguishable to the other members of the genus.

\section{References}

Bradley, J. D. 1965: Microlepidoptera. - In: Ruwenzori Expedition 19522 (12): 81-148, 215 figs. Trustees of the British Museum (of Natural History), London.

Gaedike, R. 1976: Die Epermeniidae der äthiopischen Region (Lepidoptera). - Beiträge zur Entomologie 26 (2): 451-454, 11 Fig.

GAEDIKE, R. 2004: New genera and species of epermeniid moths from the Afrotropical region (Lepidoptera: Epermeniidae). - Annals of the Transvaal Museum 41: 41-59, 66 figs.

GAEDIKe, R. 2004a: Epermeniidae (Lepidoptera, Epermenoidea). - In: MEy, W. (ed.): The Lepidoptera of the Brandberg Massiv in Namibia Part 1. - Esperiana Memoir 1: 199-202, 7 figs, col. pl. 6: Figs 4-6. 
Meyrick, E. 1909: Descriptions of Transvaal MicroLepidoptera. - Annals of the Transvaal Museum 2 (1): 1-28.

Meyrick, E. 1911: Descriptions of Transvaal MicroLepidoptera. - Annals of the Transvaal Museum 2 (4): 218-240.

MeYrick, E. 1913: Descriptions of South African MicroLepidoptera. - Annals of the Transvaal Museum 3 (4): 267-336.

Meyrick, E. 1921: Descriptions of South African MicroLepidoptera. - Annals of the Transvaal Museum 8 (2): 49-148.
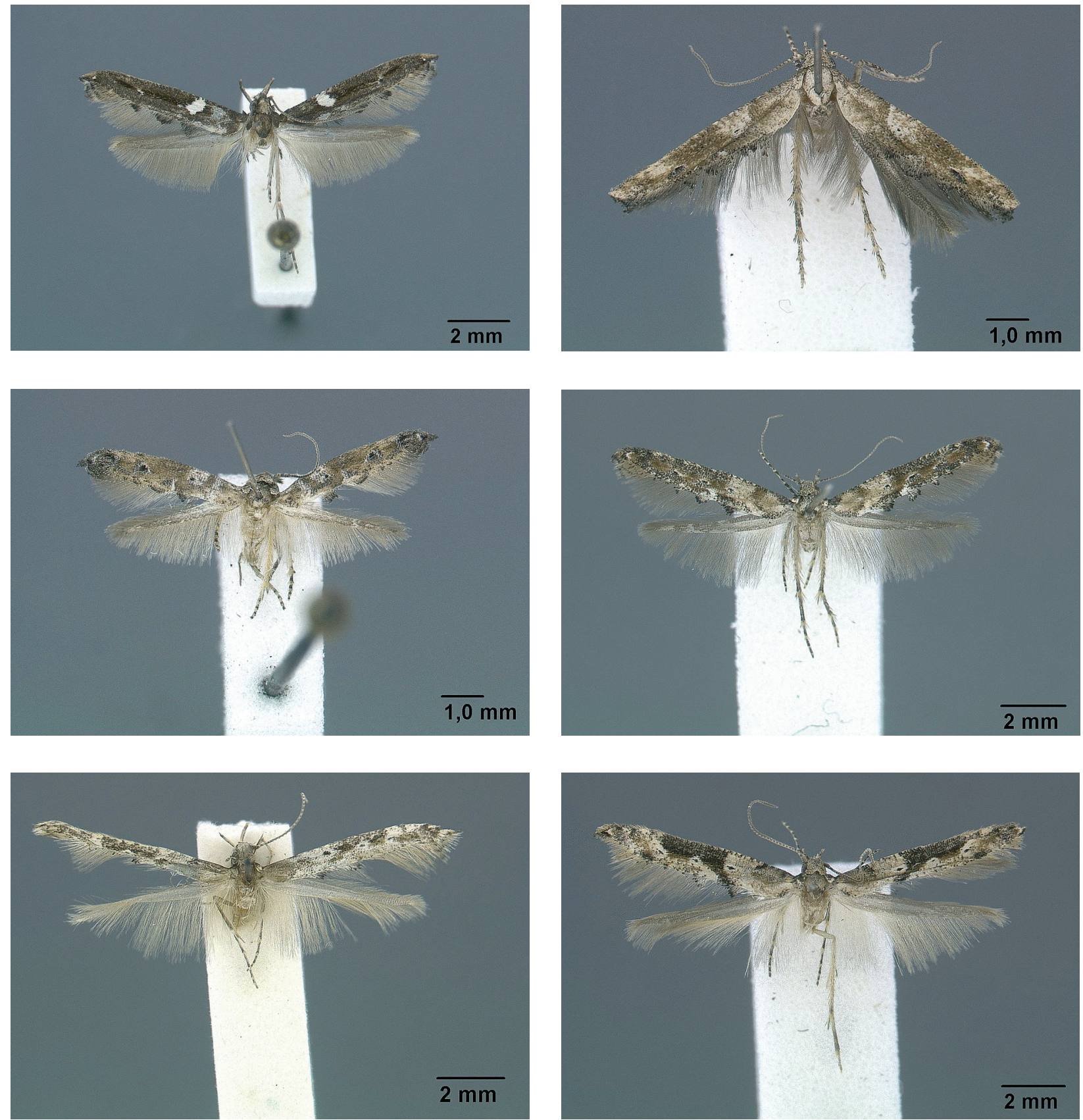

Figs 1-6: 1 - Phaulernis montuosa; 2 - Phaulernis africana; 3 - Inuncus juratae; 4 - Epermenia (Calotripis) paramalawica; 5 - Epermenia (Calotripis) karurucola; 6 - Epermenia (Calotripis) formosa. 

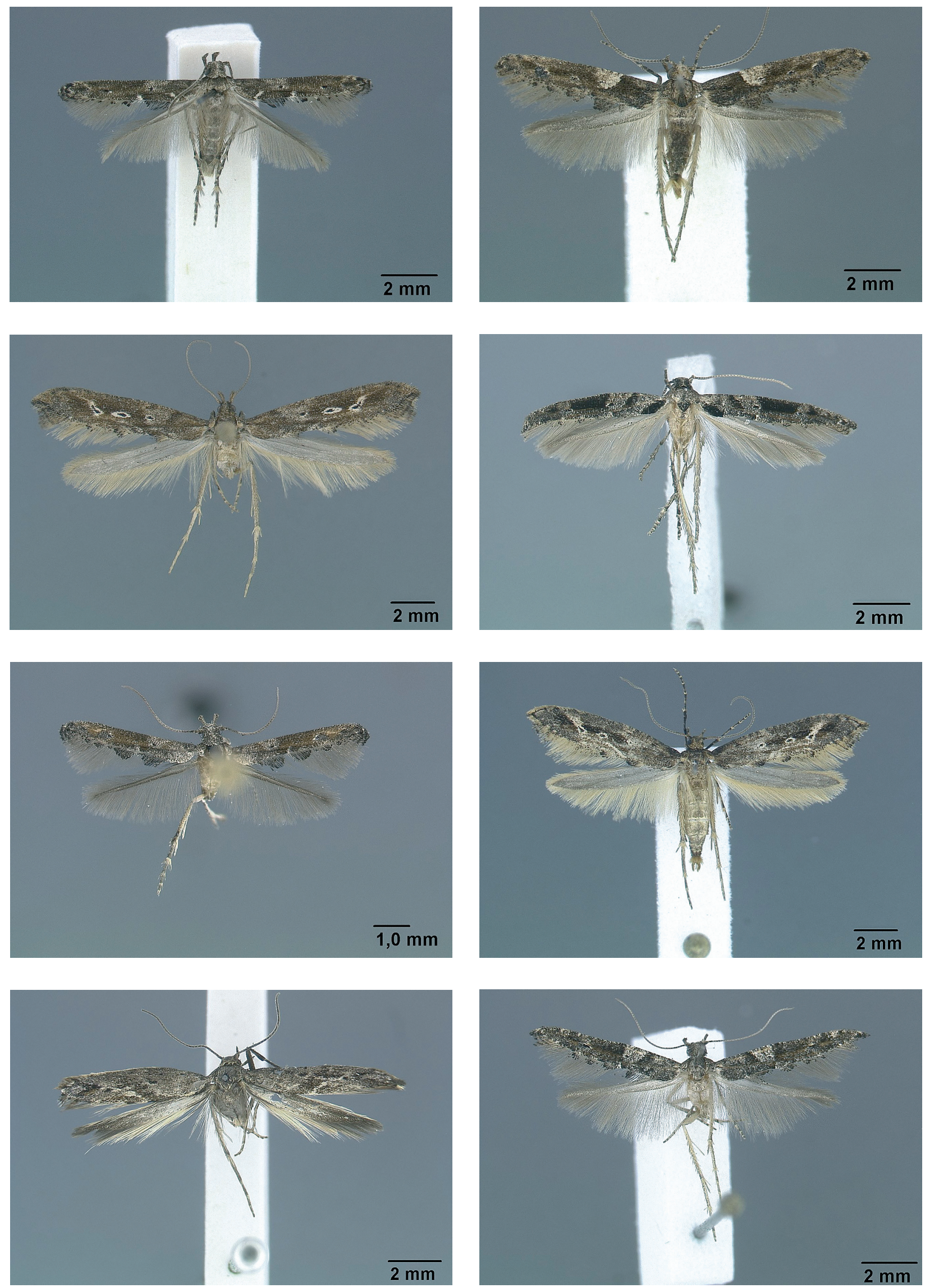

Figs 7-14: 7 - Epermenia (Calotripis) dallastai; 8 - Epermenia (Calotripis) costomaculata; 9, 10 - Epermenia (Calotripis) turicola; 11 - Epermenia (Calotripis) hamata; 12 - Epermenia (Calotripis) aarviki; 13 - Epermenia (Calotripis) ruwenzorica; 14 - Epermenia (Calotripis) tenuipennella. 

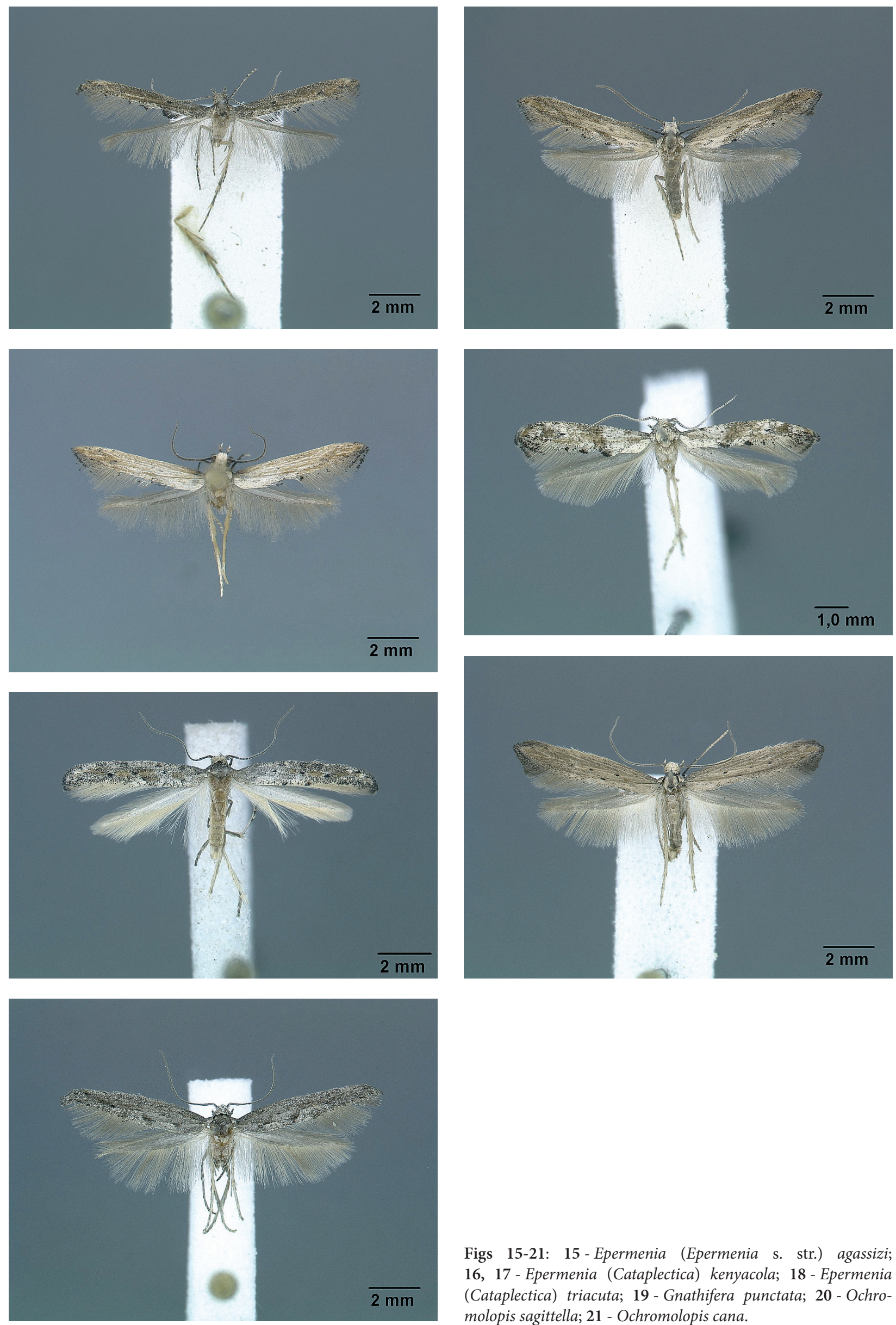

Figs 15-21: 15 - Epermenia (Epermenia s. str.) agassizi; 16, 17 - Epermenia (Cataplectica) kenyacola; 18 - Epermenia (Cataplectica) triacuta; 19 - Gnathifera punctata; 20 - Ochromolopis sagittella; 21 - Ochromolopis cana. 

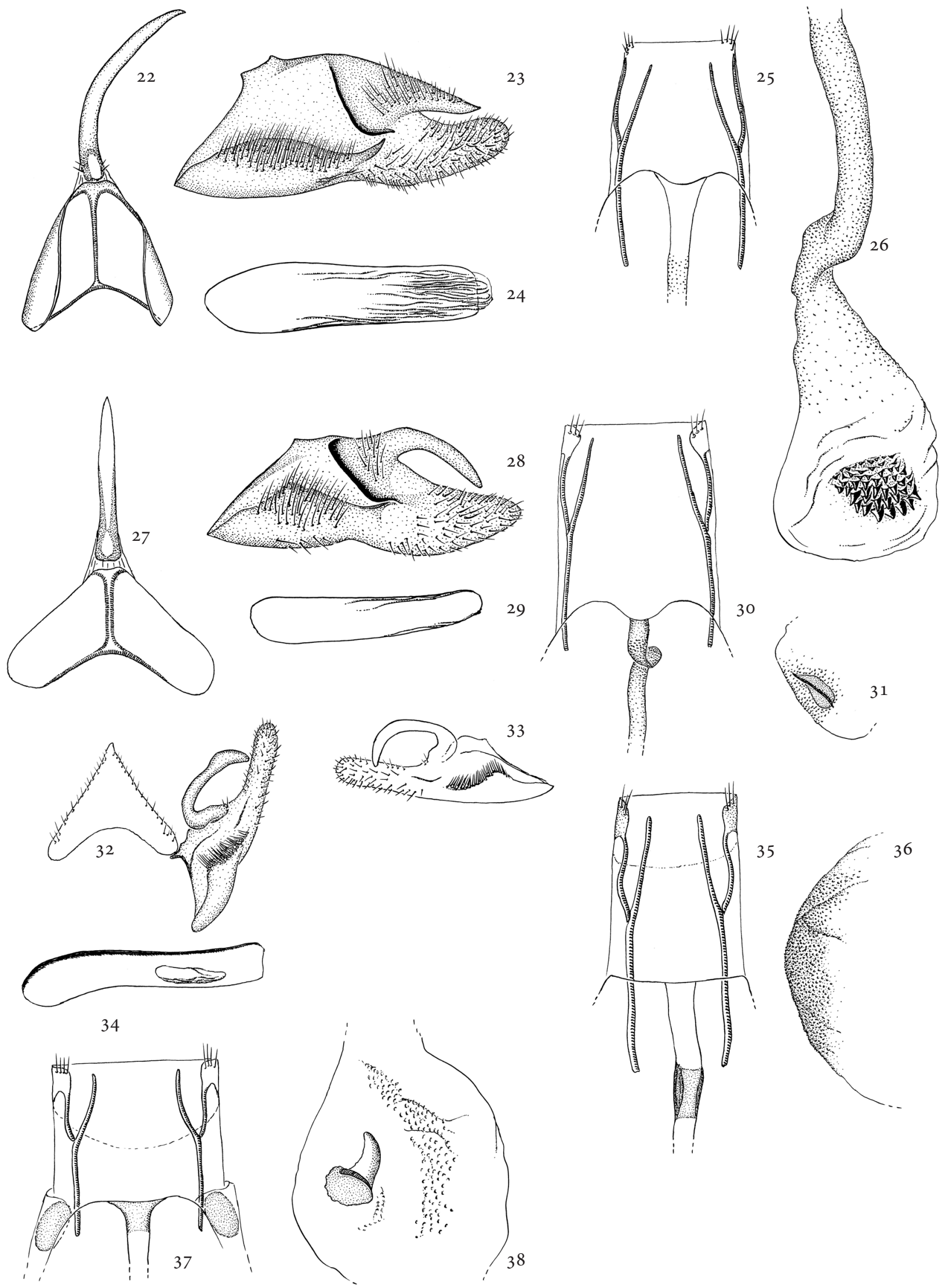

Figs 22-38: Phaulernis montuosa (male: 22 - uncus-tegumen, 23 - valva, 24 - phallus, female: 25 - segment VIII, 26 - ductus and corpus bursae with signum); Phaulernis africana (male: 27 - uncus-tegumen, 28 - valva, 29 - phallus, female: 30 - segment VIII, 31 - signum); Inuncus juratae (male: 32 - uncus, right valva, 33 - left valva, 34 - phallus, female: 35 - segment VIII, 36 - corpus bursae); Epermenia malawica (female: 37 - segment VIII; 38 - corpus bursae with signum). 


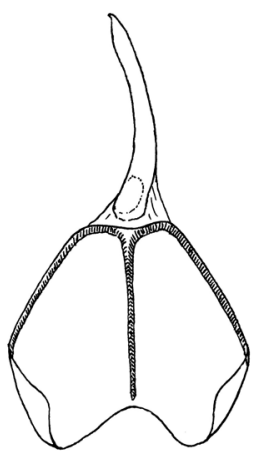

39

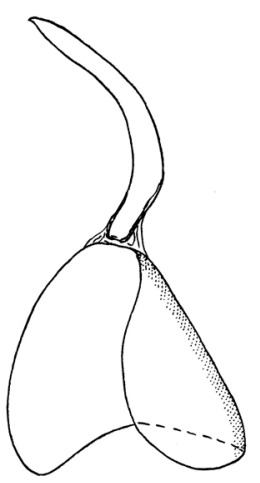

46
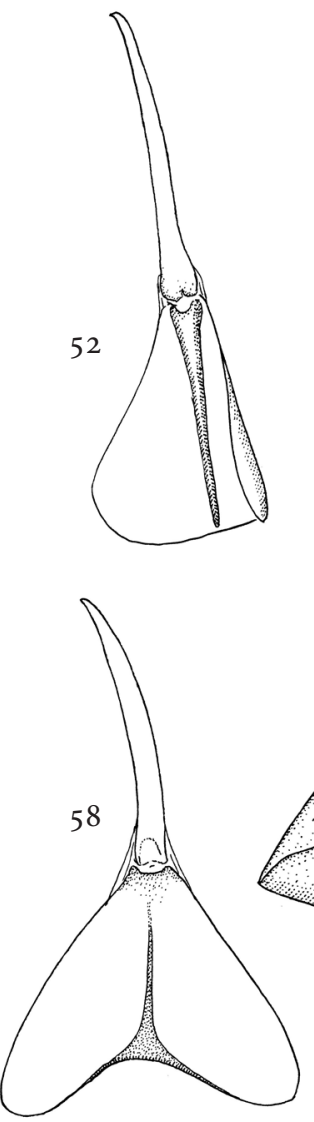
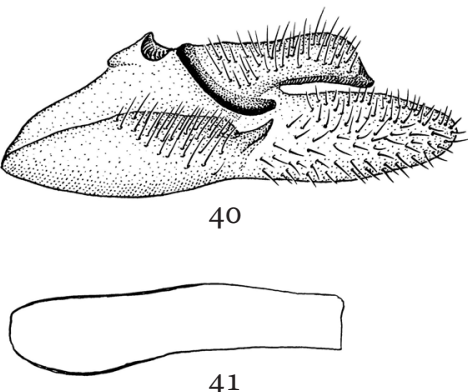

41

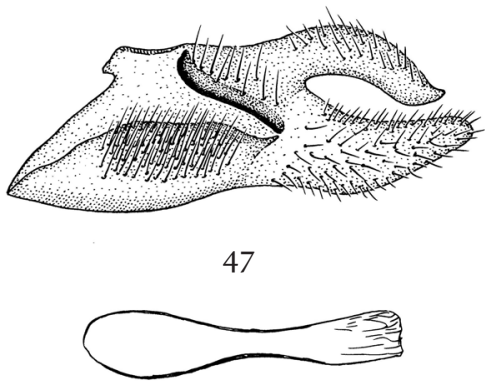

48

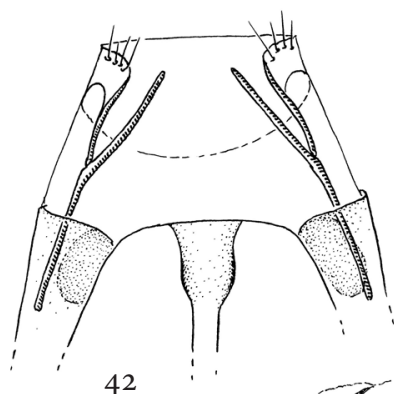

42

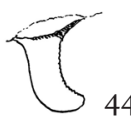

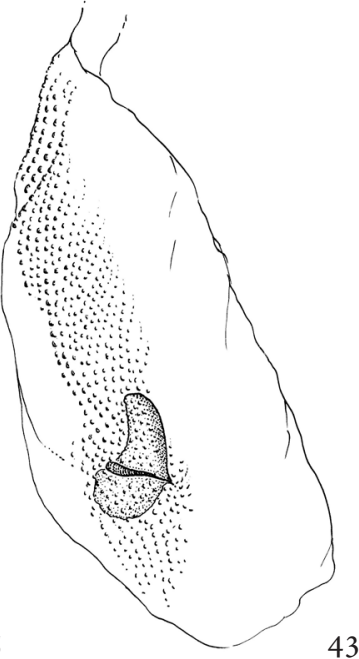

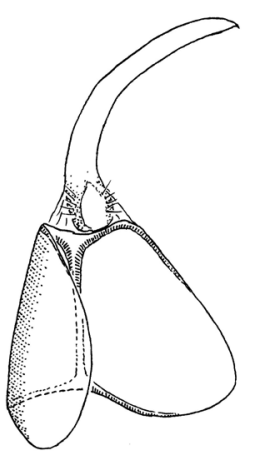

49

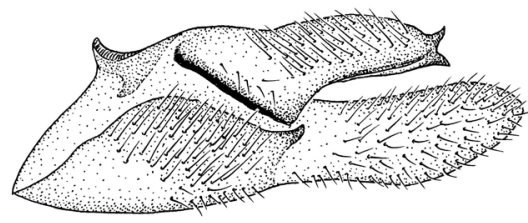

50

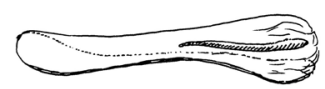

51
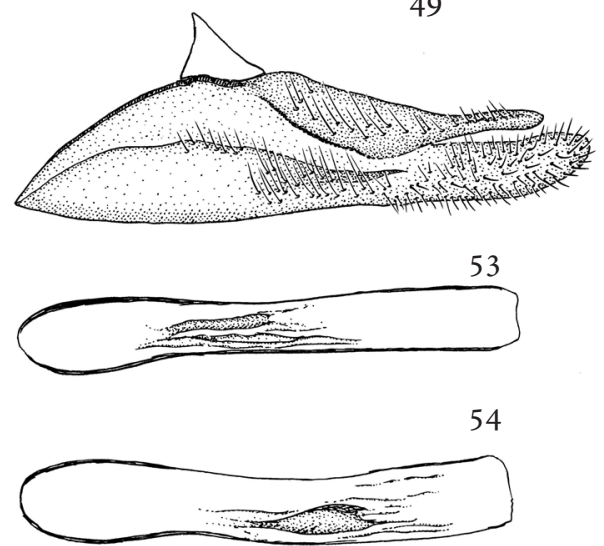

55

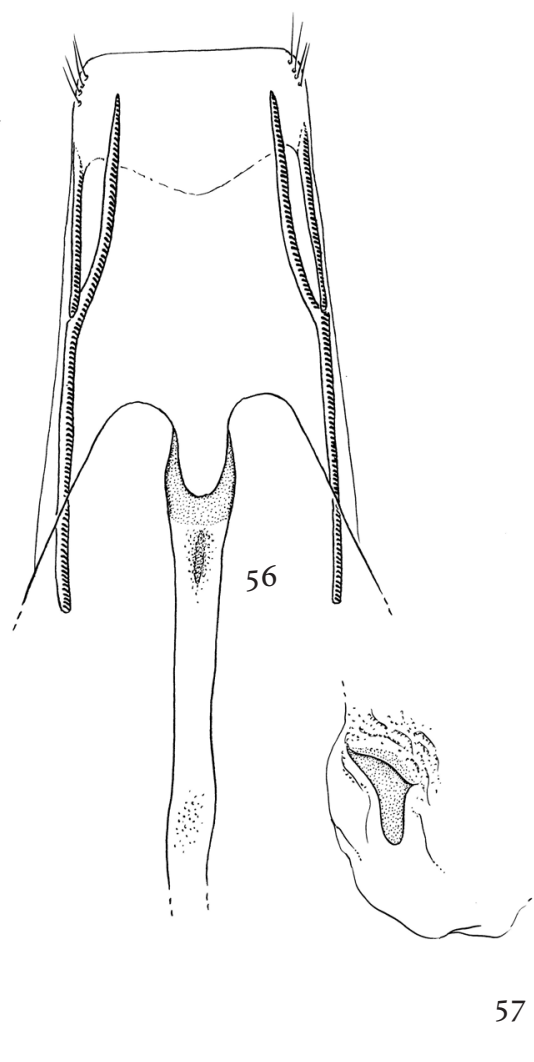

Figs 39-60: Epermenia (Calotripis) paramalawica (male: 39 - uncus-tegumen, 40 - valva, 41 - phallus, female: 42 - segment VIII, 43 - corpus bursae with signum, 44, 45 - signum, variability); Epermenia karurucola (male: 46 - uncus-tegumen, 47 - valva, 48 - phallus); Epermenia formosa (male: 49 - uncus-tegumen, 50 - valva, 51 - phallus); Epermenia dallastai (male: 52 - uncustegumen, 53 - valva, 54, 55 - phallus, variablility, female: 56 - segment VIII, 57 - signum); Epermenia costomaculata (male: 58 - uncus-tegumen; 59 - valva; 60 - phallus). 

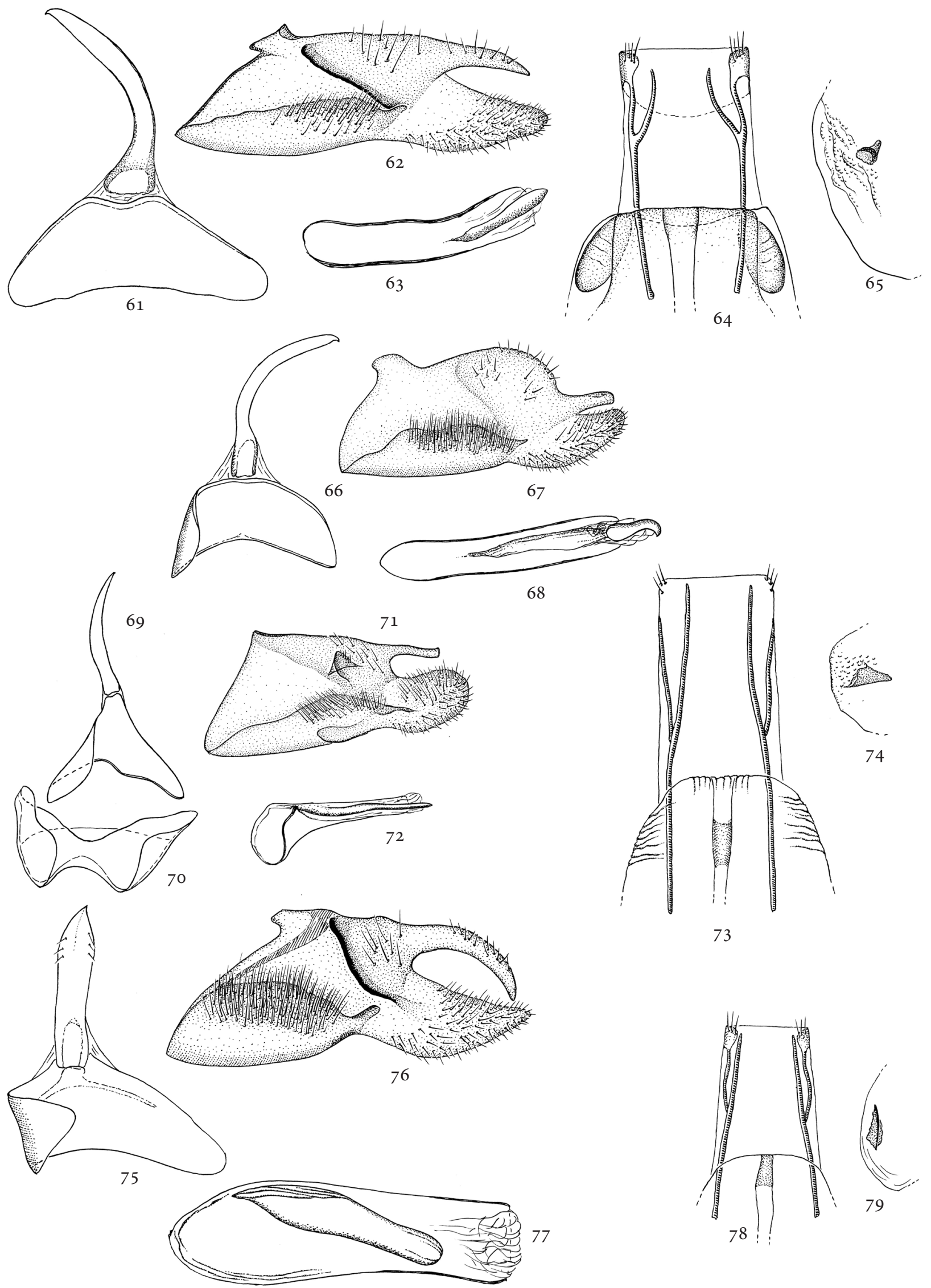

Figs 61-79: Epermenia turicola (male: 61 - uncus-tegumen, 62 - valva, 63 - phallus, female: 64 - segment VIII, 65 - sgnum); Epermenia hamata (male: 66 - uncus-tegumen, 67 -valva, 68 -phallus); Epermenia aarviki (male: 69-uncus-tegumen, 70 - vinculum, 71 - valva, 72 - phallus, female: 73 - segment VIII, 74 - signum); Epermenia ruwenzorica (male: 75 - uncus-tegumen, 76 - valva, 77 - phallus); Epermenia bulbosa (female: 78 - segment VIII, 79 - signum). 

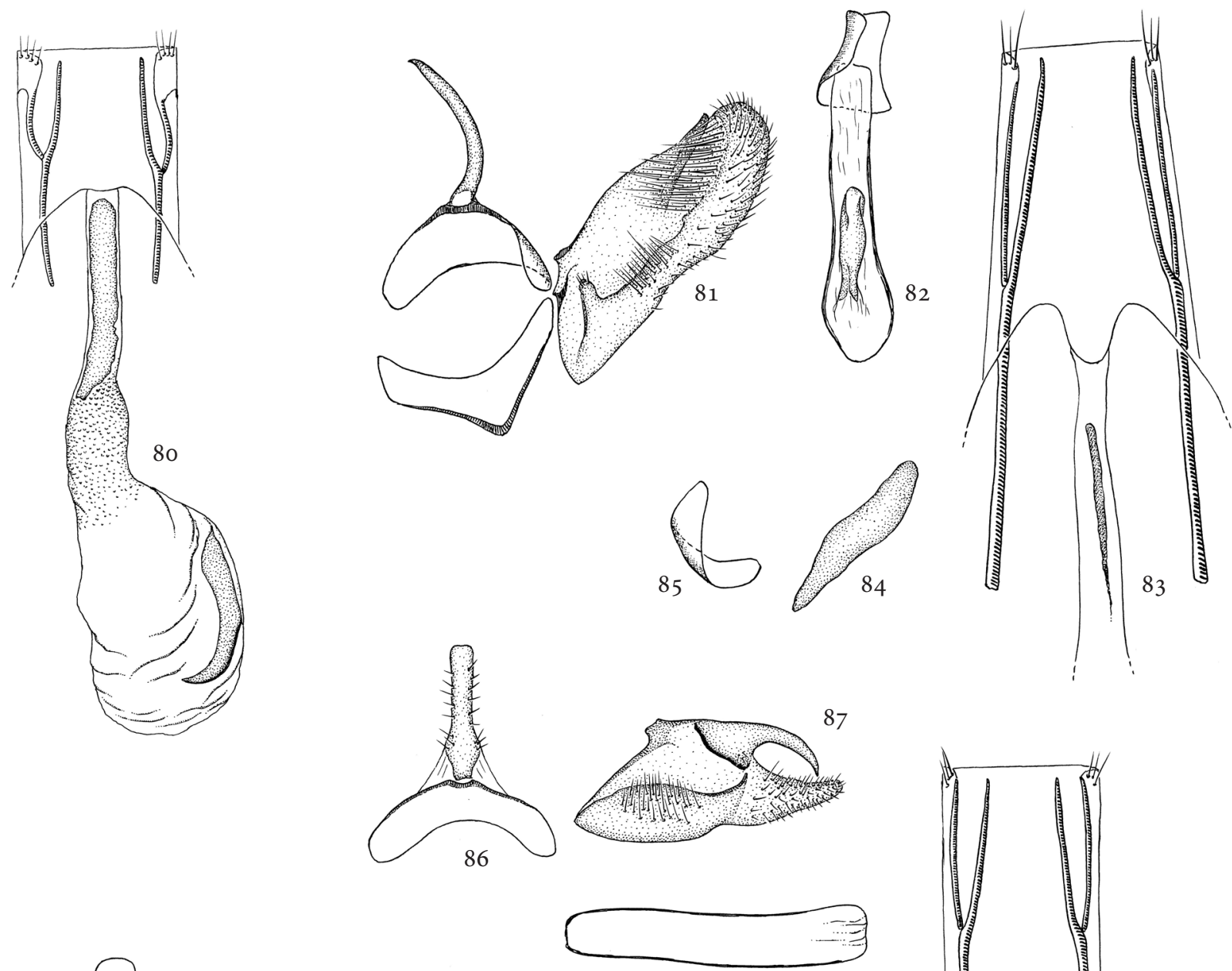

88
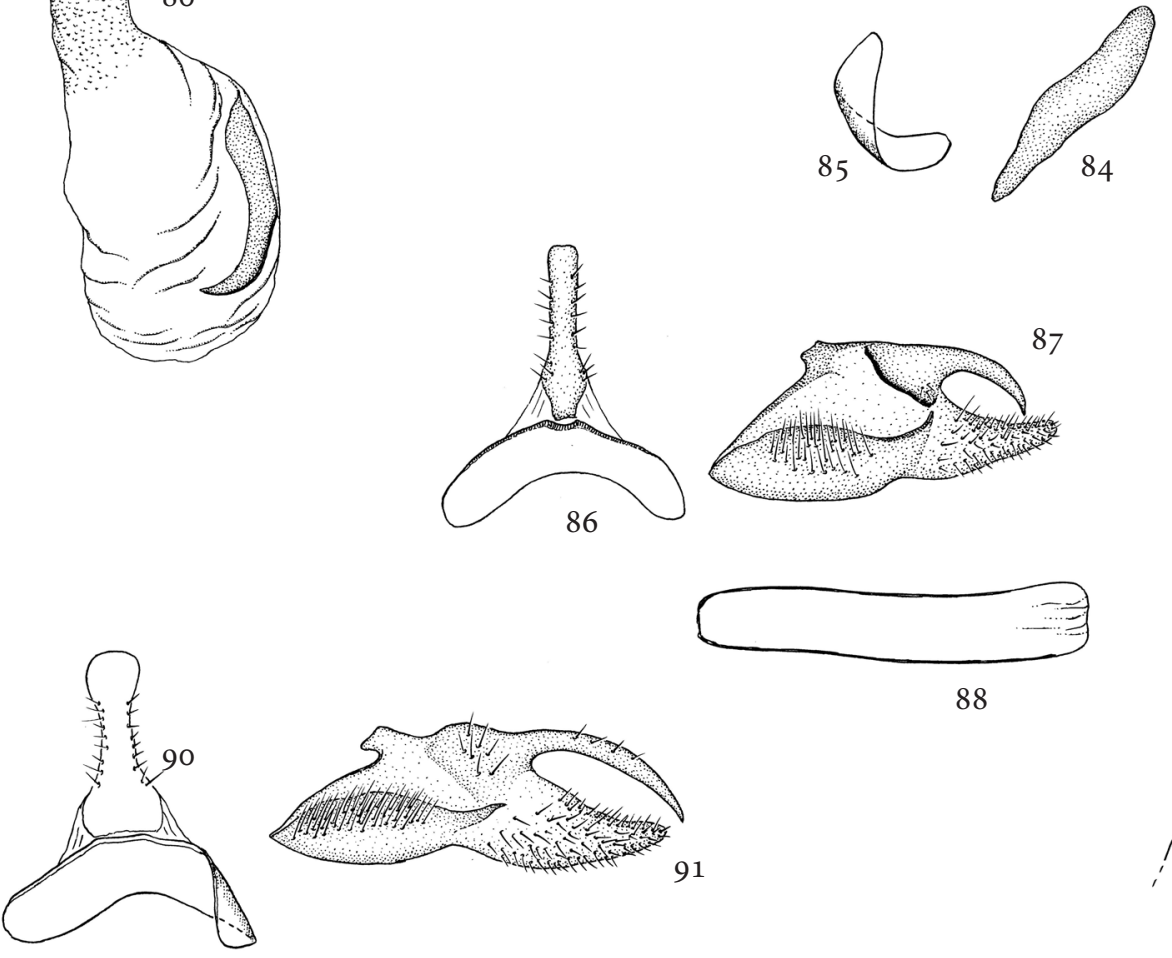

87
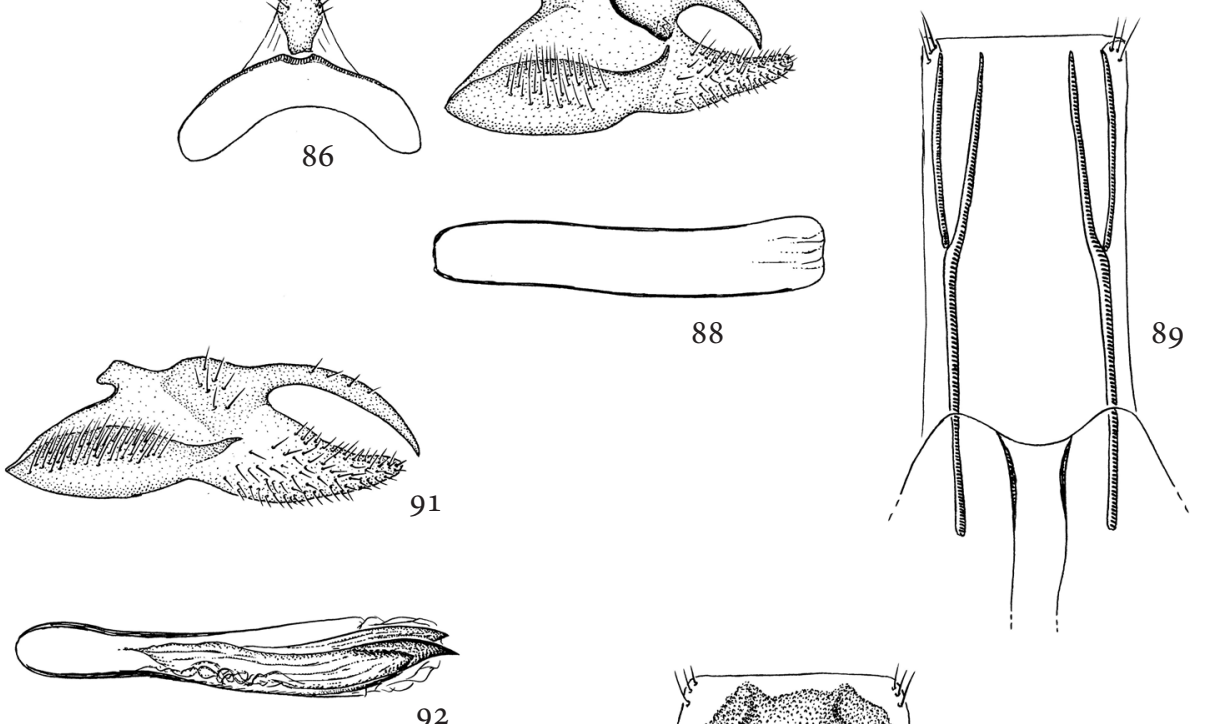

92
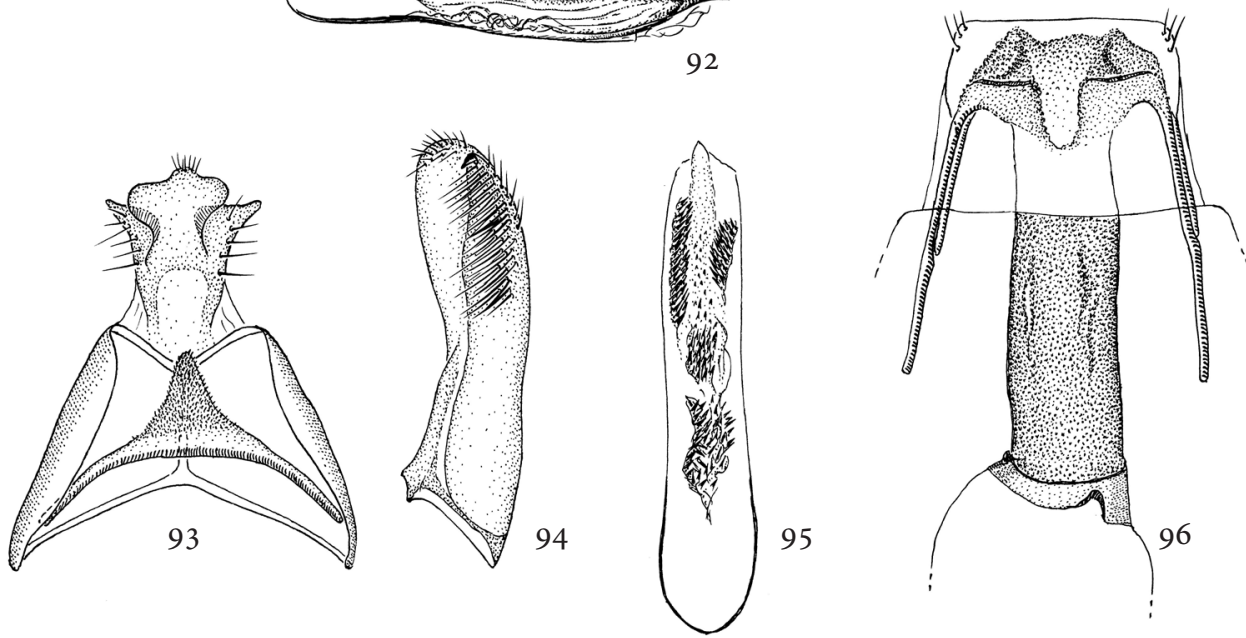

Fig. 80-96: Epermenia tenuipennella (80 - female); Epermenia agassizi (male: 81 - uncus-tegumen, vinculum, right valva, 82 - phallus, female: 83 - segment VIII, 84, 85 - signum, various view); Epermenia kenyacola (male: 86 - uncus-tegumen, 87 - valva; 88 - phallus, female 89); Epermenia triacuta (male: 90 - uncus-tegumen, 91 - valva, 92 - phallus); Gnathifera punctata (male: 93 - uncus-tegumen, 94 - valva, 95 - phallus, female 96). 

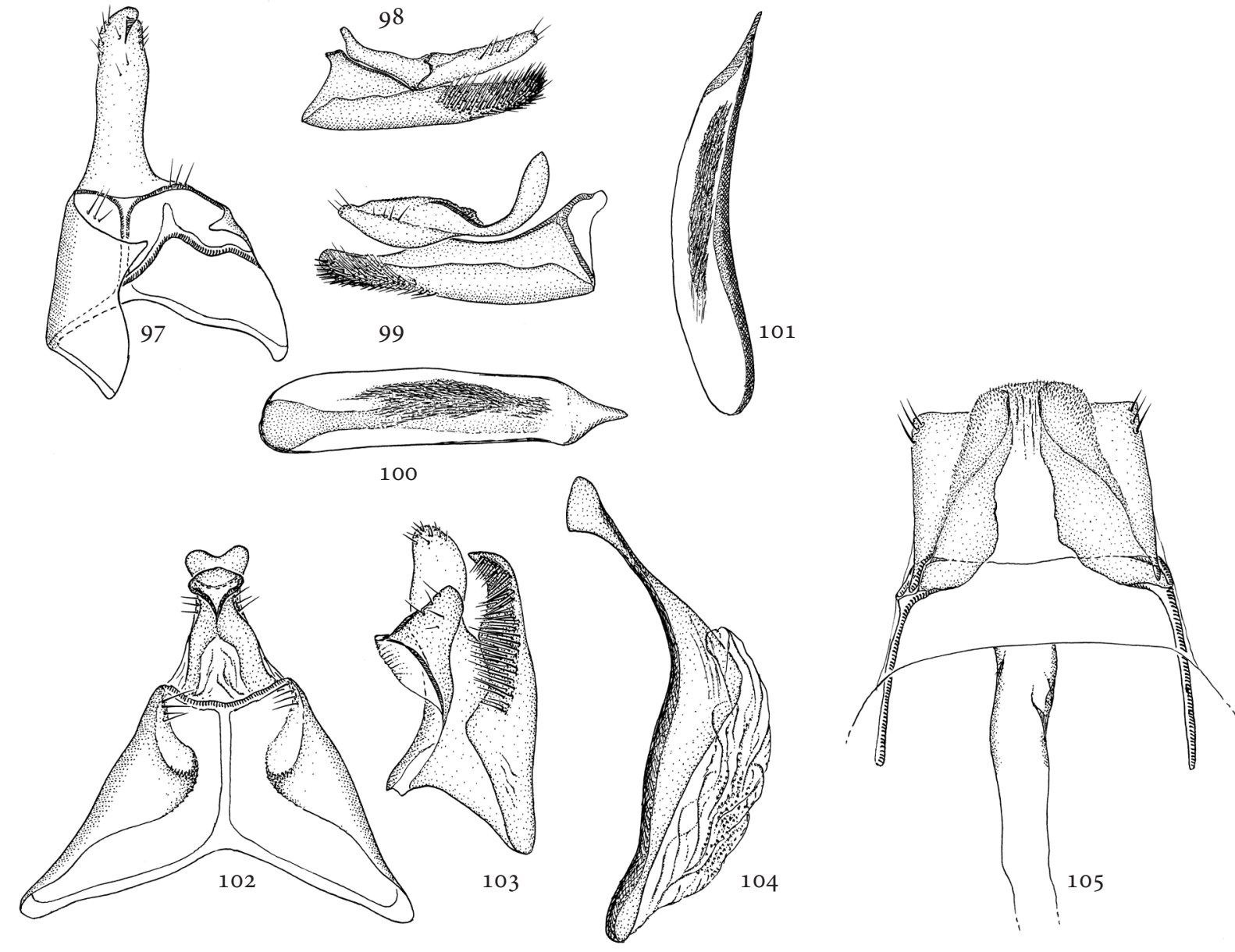

Figs 97-105: Ochromolopis sagittella (male: 97 - uncus-tegumen, 98,99-right and left valva, 100 - phallus, dorso-ventral, 101 - phallus, lateral); Ochromolopis cana (male: 102 - uncus-tegumen, 103 - valva, 104 - phallus, female: 105). 
Checklist of the Epermeniidae of the Afrotropis

\begin{tabular}{|c|c|}
\hline Taxa & Distribution \\
\hline Africepermenia tanzanica GAEDIKE, 2004 & Tansania; Kenya \\
\hline Mesepermenia malgachica GAEDIKE, 2004 & Madagascar \\
\hline Inuncus juratae sp. $\mathbf{n}$. & Kenya; Tanzania \\
\hline Phaulernis montuosa sp. $\mathbf{n}$. & Kenya; Tanganyika; Malawi \\
\hline P. africana sp. n. & Kenya; Tanzania \\
\hline Epermenia (Calotripis) minuta GAEDIKE, 2004 & Madagascar \\
\hline E. (C.) criticodes MEYRICK, 1913 & RSA; Kenya \\
\hline E. (C.) griveaudi GAEDIKE, 2004 & Madagascar \\
\hline E. (C.) conioptila MEYRICK, 1921 & Zimbabwe; Kenya \\
\hline E. (C.) maculata GAEDIKE, 2004 & Madagascar \\
\hline E. (C.) meyi GAEDIKe, 2004 & Malawi; Kenya; Ethiopia \\
\hline E. (C.) brevilineolata GAEDIKE, 2004 & Madagascar \\
\hline E. (C.) malawica GAEDIKE, 2004 & Malawi; Kenya \\
\hline E. (C.) paramalawica sp. $\mathbf{n}$. & Kenya \\
\hline E. (C.) karurucola sp. n. & Kenya \\
\hline E. (C.) formosa sp. n. & Kenya \\
\hline E. (C.) dallastai sp. n. & Kenya \\
\hline E. (C.) costomaculata sp. $\mathbf{n}$. & Kenya \\
\hline E. (C.) turicola sp. n. & Kenya; Tanzania \\
\hline E. (C.) hamata sp. n. & RSA \\
\hline E. (C.) aarviki sp. n. & Tanzania; Kenya \\
\hline E. (C.) ruwenzorica sp. n. & Kongo \\
\hline E. (C.) bulbosa GAEDIKe, 2004 & RSA; Kenya \\
\hline E. (C.) bicornis GAEDIKE, 2004 & RSA \\
\hline E. (C.) oriplanta BRADLEY, 1965 & Kongo \\
\hline E. (C.) philoritis (BradLey, 1965) & Kongo \\
\hline E. (C.) epirrhicna MEYRICK, 1938 & Kongo \\
\hline E. (C.) tenuipennella sp. $\mathbf{n}$. & Kenya \\
\hline E. (Epermenia s. str.) agassizi sp. n. & Kenya \\
\hline E. (Cataplectica) mineti GAEDIKE, 2004 & Madagascar \\
\hline E. (C.) kenyacola sp. $\mathbf{n}$. & Kenya; Malawi; Ht. Katanga \\
\hline E. (C.) triacuta sp. n. & Namibia \\
\hline E. (C.) iniquella (Wocke, 1867) = ochrodesma MeYrICK, 1913 & RSA; Kenya \\
\hline Gnathifera proserga (MEYRICK, 1913) & RSA \\
\hline G. punctata sp. n. & RSA \\
\hline Ochromolopis xeropa (MEYRICK, 1909) = praefumata MEYRICK, 1911 & RSA \\
\hline O. pallida GAEDIKE, 2004 & Madagascar \\
\hline O. ithycentra (MEYRICK, 1926) & RSA \\
\hline O. namibica GAEDIKE, 2004 & Namibia \\
\hline O. sagittella sp. n. & Kenya \\
\hline O. cana sp. n. & RSA \\
\hline
\end{tabular}

